\title{
How Are Teenage Students in a Private Christian School Using Social Media and What Are the Implications for Education?
}

Kimberly K. Beavers

Cedarville University

Follow this and additional works at: http://digitalcommons.cedarville.edu/education_theses

Part of the Curriculum and Instruction Commons, Curriculum and Social Inquiry Commons, Educational Methods Commons, Instructional Media Design Commons, and the Secondary Education and Teaching Commons

\section{Recommended Citation}

Beavers, Kimberly K., "How Are Teenage Students in a Private Christian School Using Social Media and What Are the Implications for Education?" (2014). Master of Education Research Theses. 72.

http://digitalcommons.cedarville.edu/education_theses/72 
Running head: HOW ARE TEENAGE STUDENTS USING SOCIAL MEDIA

How Are Teenage Students In A Private Christian School Using Social Media And What Are The Implications For Education?

Kimberly K. Beavers

Cedarville University

July 30, 2014 


\section{Table of Contents}

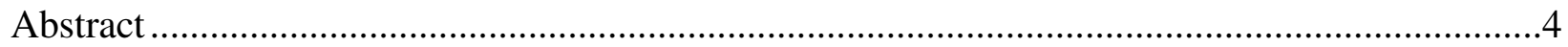

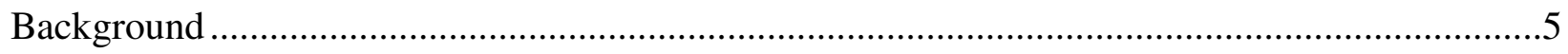

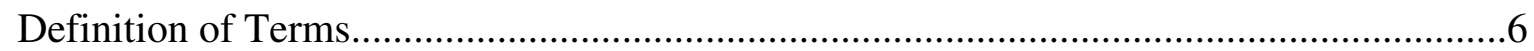

Summary of Literature Review ...........................................................................

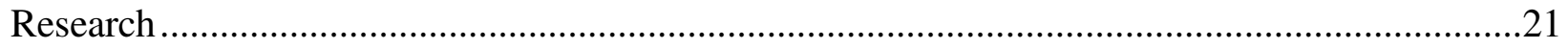

Statement of the Research Topic ........................................................................21

Statement of the Research Problem .........................................................................21

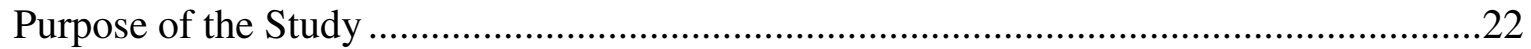

The Research Question ......................................................................................26

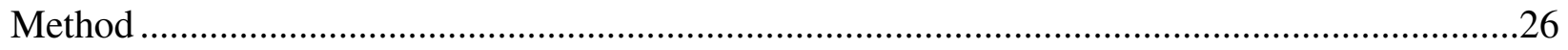

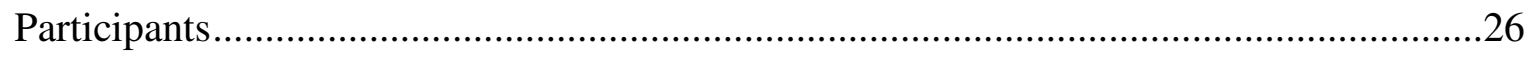

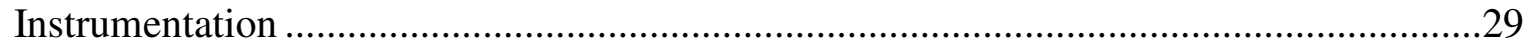

Questionnaire Development.................................................................................30

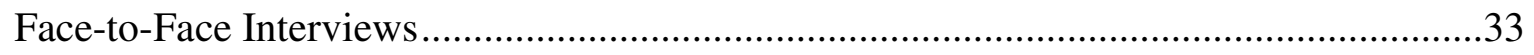

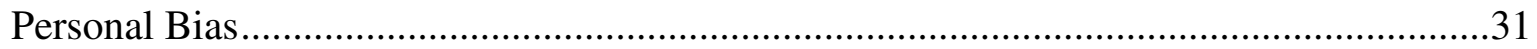

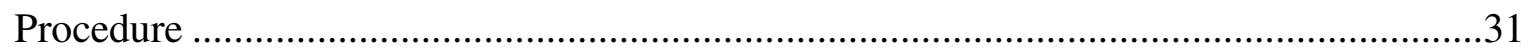

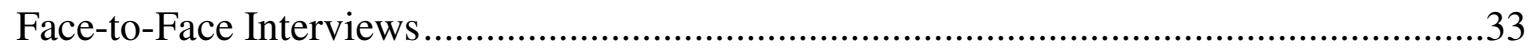

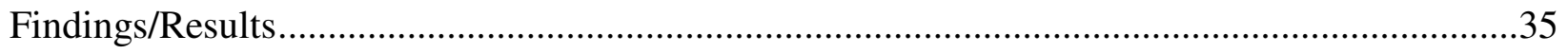

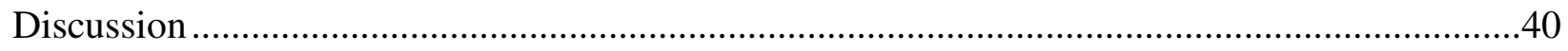

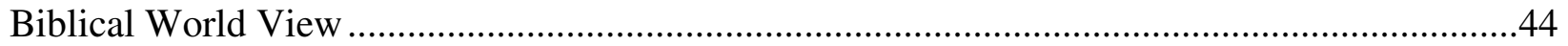

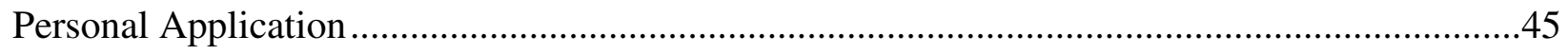

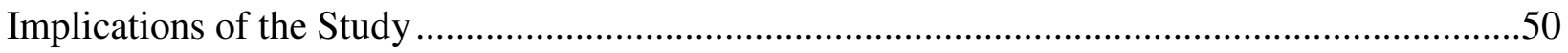


Conclusion

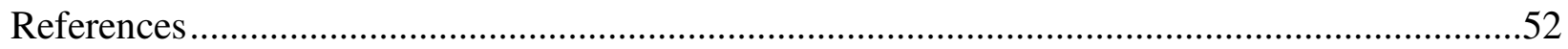

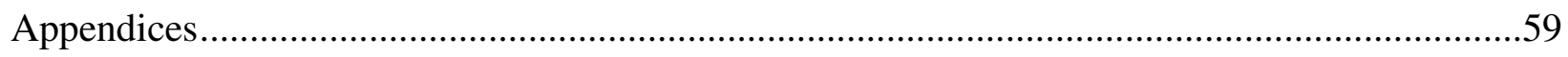

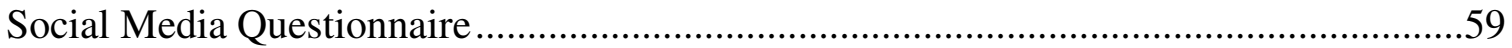

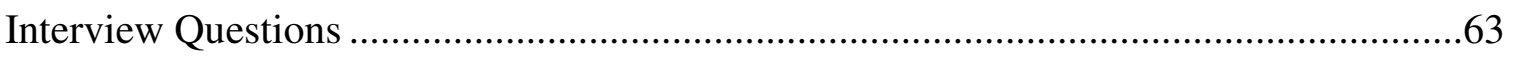

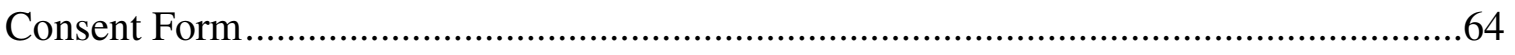

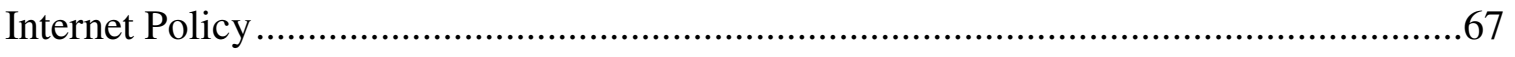

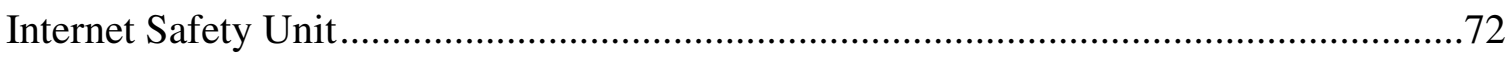




\begin{abstract}
The purpose of this study was to research this question in a private Christian high school, "How are teenage students using social media and what are the implications for education?" The definition(s) of social media are provided, along with a qualitative research study, illustrating the information concerning the participants in a private Christian high school, relating the research findings to previous compiled literature reviews concerning incorporating social media in a high school educational classroom. The methods, instrumentation, and procedures used are described. The results provide agreements and disagreements from the influence of social media. The analysis section of the research presented provides concise summaries from the sample population used and will demonstrate influences through philosophical and theoretical perspectives and provides social media through a Christian worldview from both a biblical and critical analysis standpoint.
\end{abstract}

Keywords: technology, social media, Twitter ${ }^{\circledR}$, Facebook ${ }^{\circledR}$, cyberbullying, social networking sites 
Social Media 5

\section{How Are Teenage Students Using Social Media and What Are the Implications For Education?}

Ever wondered if social media technologies should be used in a private Christian or a traditional high school classroom and what effects could be used to engage students while using social media technologies in a high school classroom? Would learning increase or decrease with using social media technologies in high school classes in a private Christian school or a public high school? Research has been conducted at the collegiate level of incorporating social media technologies; little has been conducted in using social media methods with high school students in a traditional high school or in a private Christian high school.

The qualitative methods, results, and a discussion of the findings collected from a small sample of private Christian high school student's social media influence from completing a questionnaire and being interviewed will be analyzed as well as the methods I used to conduct my research, introduce the research statement, questionnaire development, procedures, and findings gleaned from my research. I will also summarize and analyze the effects of an educational policy of social media and technology influences in a private Christian high school educational classroom, and provide the background and articles researched on this topic. The critical analysis of the theories presented will be discussed for educational institutions and instructors.

I chose this topic because I teach technology to private Christian high school students at Cuyahoga Valley Christian Academy (CVCA) and was curious to see if any instructors were currently engaging students with social media venues. Social media influence is apparent when talking with Christian high school students. Using social media to engage learners in learning is an interest that I have been researching for the past few years, since I began to pursue my 
Master's in Education degree at Cedarville University. Instructional technology is influenced by good instructional methods that take advantage of what social media technologies have to offer (Lin, Hoffman, and Borengasser, 2013). The educational development will be addressed as well as the conditions for learning. Social cognitive theory are some of the many cognitive and motivational theories that when used with technology improves learning such as with cognitive load theory, and the four components include instructional design, scaffolding, metacognition, and self-regulating learning (Gruber, 2013a). Biblical perspectives of how social media and technology influences the role as Christian educators will be discussed.

\section{Definition of Terms}

Social Media - Technological development using programs in an online format in the cultural and social practices of users (Lin, Hoffman, \& Borengasser, 2013)

Technology - a manner of accomplishing a task especially using technical processes, methods, or knowledge (Merriam Webster, 2014)

Cyberbullying - the electronic posting of mean-spirited messages about a person (as a student) often done anonymously (Merriam Webster, 2014)

Twitter $^{\odot}$ - Social Media program where one talks in less than 140 characters and provides updates on what they are doing (Tech Factor, 2009)

Facebook $^{\odot}-$ Facebook $^{\Theta}$ is a popular free social networking website that allows registered users to create profiles, upload photos and video, send messages and keep in touch with friends, family and colleagues (Dean, 2009)

Instagram $^{\Theta-}$ Instagram is free online program and social network that enables users to take, edit and share photos with other users via Instagram's own platform, email, and social media sites including Twitter, Facebook, Tumblr, Foursquare and Flickr. (Rouse, 2014). 
$21^{\text {st }}$ Century Skills - refers to a broad set of knowledge, skills, work habits, and character traits that are believed—by educators, school reformers, college professors, employers, and others—to be critically important to succeed in today's world, particularly in collegiate programs and modern careers (The Glossary of Educational Reform, 2014).

Social Networking Sites - Social Networking sites are defined to include Twitter $^{\circledR}$, Facebook $^{\circledR}$, YouTube $^{\odot}$, Google+ $^{\circledR}$, Instagram $^{\circledR}$ and LinkedIn ${ }^{\odot}$.

\section{Literature Review}

Social media is defined as "technological development using programs in an online format in the cultural and social practices of users." (Lin, Hoffman \& Borengasser, 2013). Social media has many components such as Facebook $^{\circledR}$, Twitter $^{\circledR}$, wiki’s, blogs, mobile apps, smartphones, and social network sites. How news spreads in social networks, such as Facebook ${ }^{\odot}$ and Twitter $^{\odot}$ are reshaping the way that people communicate with each other and is becoming a critical aspect of social media technology in education. Social media technology has many different aspects to it. Some of those aspects include a variety of types, educational issues, and ethical dilemmas to consider when implementing social media technology in the classroom. Authors agree that social media technology should be used in classrooms, as long as there are policy, procedures, guidelines, and the necessary precautions taken to protect oneself and the institution in the process.

Twitter $^{\circledR}$

Twitter $^{\odot}$ is a social networking site that provides the ability to have discussions and opportunities for students to continue conversations outside of the classroom to further the learning process. “The Higher Education Research Institute reported that 94\% of first year college students use social networking websites and then of those who have social media 
websites statistics shows that $85 \%$ of students have accounts on Facebook ${ }^{\circledR}$." (Lin, Hoffman, \& Borengasser, 2013). Twitter $^{\odot}$ can be used to engage the students in academic and psychosocial development and improve grades. "In a Twitter ${ }^{\odot}$ network, 45.6 million of its 51.2 million members will hear the information within eight rounds of communication." (Doer, Fouz, \& Friedrich, 2012). The conclusion is that once one person learns something and shares it with others, they in turn will share it with their neighbors, and the information will spread. Using Twitter $^{\odot}$ in the classroom though is different from using Twitter $^{\odot}$ personally (Lin, Hoffman, \& Borengasser, 2013). Educators should not have infrequent posts, uninteresting blogs, and limited interaction with students because this could kill any chance of capturing a person's interest in social media interaction (Bhat, Chang, \& Linscott,2010; Kolus, 2010). Some students that are new to Twitter $^{\odot}$ do not appreciate the social media technology interaction in classrooms due to having to learn how to use the social media technology. The students are also concerned about privacy issues, how the social media interaction could affect the class instruction, their assessments, and the learning outcome (Lin, Hoffman, \& Borengasser, 2013). Teachers are helping students build an ecosystem for learning to flourish and empowering them to set and manage their learning goals (Robinson, 2010).

\section{Gender and Racial Use}

If students who did not have access to technology, and did not participate in new technologies would be at a disadvantage over those, who have access and are able to participate is a concern using social media technology sites. The following components were compared: males vs. female users, education level of parents, computer skills of parents and students, racial and ethnic groups, and the ages of students and parents, hours of use, the age level of users, and how as educators we should try to implement these concepts to reach the different types of 
learners in our classrooms. According to Ahn, (2011), “60\% of white and black youth use social media, and $40 \%$ of Asian and Hispanic youth use social media. Sixty-eight percent did not have a computer or Internet access and still connected to social media sites. Female teenagers use social media more than males do. Parents with a high school education or higher resulted in their children being in social media sites more often because they used social media themselves. Students would connect at home, at school, or in their community." Parents with wealth provide more opportunities for students to use social media and have their children use social media at an earlier age (Levy, 2010).

\section{High School Elective Classes}

In Christian high school elective classes such as Marketing, Business, or extra curriculum programs provides the opportunity to use social media to promote information or communication, it only takes one person with many followers for the request to go global. Social media can serve as a purpose to provide a branding opportunity. Self-promotion is a way to promote yourself on the social media venues. Companies have policies for email, and electronically stored information, but highlighted that most companies do not have in place ways to secure backups for their social media information. Major issues could be avoided if schools have compliance with regulations established. As a Christian educator, one of our objectives is to teach life skills, such as engaging students to use social media technology for classroom instruction, and in their career choice, which could utilize different tools such as social media technology throughout their life. Instructors should consider planning to learn and develop these concepts for classroom instruction and extracurricular activities. 


\section{Ethics of Social Media in Education}

Madhava (2011) discussed ten things to preserve in social media information for litigation purposes, which is one of the areas of negativity concerning social media technologies in the classroom. The ten items began with organizations needing to incorporate social media technologies. The educational institution needs to preserve social media texts, website pages, and social media files. Using application programming interfaces to capture, archive, and review data from the web and social media archiving solutions needs to be customized. Setup or installation requirements for technological needs and robust search capabilities of the preservation are necessary in order to find the information quickly, efficiently, and effectively. At the onset, companies should create a database that can be searched for the components stored. Capture data in real time and think about how content for legal holds will be protected. "The key to social media preservation is not only to have it preserved, but to have it easily accessible, indexed, and search-enabled." (Madhava, 2011).

\section{Cyberbullying and Digital Citizenship}

The digital citizenship arena Levy (2010) mentioned four areas of concentration - protect personal information; social forums, cyberbullying, and being able to judge properly the information presented in an online article. Describing internet safety issues that could arise from using social media in the classroom and preparing teachers to be trained also were two of the key themes presented. The history of cyberbullying in the late 1990's and early 2000's tells how educators focused their finances on hardware and connectivity, mainstream media, and online predators. Educators focused primarily on the two P's: predators and pornography (Levy, 2010). The history of e-learning, use of smartphones in the classroom, E-books, Social Networking Sites (SNS) and social media technology in the classroom are important. Social networking sites 
are considered the newest applications and services that collaborate with interaction and collective action in multimedia information. It is allowing multi-tasking at a new level for individuals in not only connectivity, but also in E-Commerce, working relationships, and human interaction. It communicates how to use this aspect to increase learning in the classroom through blogs, wikis, and group environments for student projects according to Shim (2011), "about 74\% of people use this type of technology". Cyberbullying involves repeated harm willfully inflicted on another person through technology and can include teasing, name calling, hurtful stories, embarrassing photos, lies, false rumors, mean or threatening notes, threats of violence or death, and other hurtful actions (Miller, Hufstedler, 2009). In a separate annual survey of 850 students at CVCA on cyberbullying the students stated $42 \%$ of students have been bullied on-line; $53 \%$ admitted that they have said hurtful things online; $58 \%$ have not told their parents or another adult when someone has been mean or hurtful to them online (CVCA, 2014). Cyberbullying can occur at any time day or night. The victims have difficulty escaping the harassment. Victims of cyberbully usually show signs or symptoms such as a sudden drop in grades, increased absences and truancy, change in interests, depression, and cutting classes. Victims also experienced negative feelings such as worry, fear, anger, and depression, or stress (National Crime Prevention Council, 2012). “Over 58\% of students felt Cyberbullying was equally harmful or more harmful than physical bullying." (Miller, Hufstedler, 2009). Anonymity allows cyberbullies to make victims feel helpless, and is more dangerous than traditional bullying (Patchin \& Hinduja, 2006). $20 \%$ to $25 \%$ of children have experienced either physical or emotional bullying and this is an issue that cannot be ignored by parents or school personnel (Finkelhor, Ormrod, Turner, \& Hamby, 2005). Cyberbullying messages can be sent to large numbers of people in just a moment. 
Technology curriculum usually includes information on cyberbullying, privacy, viruses, and copyright infringement (I-safe.org, 2014). Technology integration in education helps other teachers learn how to use social media in the classroom. In a 2010 survey from the National Cyber Security Alliance, just 50 percent of teachers who participated in the study felt prepared to discuss cyberbullying. Schools at one point or another could have cases that involve cyberbullying and social media ethics. Schools report difficulty in preparing policy and discipline that identifies cyberbullying and outlines effective responses to cyberbullying (Willard, 2007a, 2007b). Schools may be held legally accountable for failing to respond appropriately to cyberbullying (Kowalski, Limber, \& Agatston, 2008; Willard, 2007a). Schools and school district personnel have been held liable for harm caused by Cyberbullying that resulted from negligence. Here is a case that occurred in 2011 in Berkeley, West Virginia concerning a senior who created and posted to a website ridiculing a fellow student. The United States Court of Appeals for the Fourth Circuit held that the First Amendment did not protect a student from school discipline for Internet bullying. The school suspended her for five days for the inappropriate behavior. The School argued that the punishment was justified because the speech invited others to indulge in hateful conduct, which caused an in-school disruption. The student sued the school stating that the suspension violated her free speech and due process rights under the First and Fourteenth Amendments. Even though she wrote the text outside of school hours and was performed in private, the United State District Court for the Northern District of West Virginia found that the school had the right to take action against the student for her speech. "The Court recognized that the School had authority to discipline speech that: (1) materially and substantially interfered with the requirements of appropriate discipline in the operation of the school; and (2) collided with the rights of others. Because Kowalski used the 
website to orchestrate a targeted attack on a classmate, and did so in a manner that was sufficiently connected to the School's environment, the trial court's decision was correct." (Shaukat, 2011). The case was called Kowalski v. Berkeley County Schools No. 10-1098 (4th Cir. 2011).

Teachers need to be educated about the need for bullying and cyberbullying prevention programs (Hirschstein, Edstrom, Frey, Snell, \& McKenzie, 2007; Payne, Gottfredson, \& Gottfredson, 2006). All educators need to understand the importance of reporting cyberbullying cases to administrators and to parents (Stauffer, Heath, Coyne, \& Ferrin, 2012). The power of teacher buy-in is very important. Teachers are likely to report cyberbullying to school administrators when it happens at school, and they are more likely to talk with the victim and the bully and take away the bully's privileges (Stauffer, Heath, Coyne, \& Ferrin, 2012). Being prepared to combat this with having a process in place and administrative policies defined is critical in regards to presenting the information to parents and to the court. The importance of parental involvement in preventing cyberbullying is crucial. Multiple studies have indicated that students are more likely to cyberbully others when there is a lack of parental monitoring of online activities (Vandebosch \& Van Cleemput, 2007; Ybarra \& Mitchell, 2004a). Parents need educating too concerning good digital citizenship and cyberbullying and intervention techniques. Parents may not be aware of the extent that their child is being harmed or being harmful to others. Professional development for parents should include topics such as where to place the computer in the home, what online communities your child is involved in, how you can access their account, checking out their friends, the Internet browser history (tells you where they have been online), and install monitoring programs for their safety. 
Teachers may need to consider how to teach students to be good digital citizens instead of focusing on only the negative aspects in using Social Media. For most instructors this concept is a new concept and this needs to be taught in teacher training programs in order for instructors to feel comfortable in engaging in social media technologies in classroom activities (Levy, 2010). Professional development for teachers should include what is cyberbullying, the real consequences of severe and continuous cyberbullying along with engagement in participatory planning and professional development that includes district technology staff, parent organizations, social services agencies, and law enforcement (Willard, 2007a). According to Rivero (2011), bullying becomes cyberbullying, note passing becomes sexting, and social media becomes a huge liability to learning. Some actions to take to stop cyberbullying as an instructor are to teach the students how to block the sender and ignore the messages, as well as protect personal information, and inform an adult of the situation immediately. (Miller, Hufstedler, 2012).

The effects of cyberbullying range from depression and fear to anger and frustration and even suicide. (Patchin \& Hinduja, 2010). Cyberbullying does not "toughen kids up", has longlasting negative effects on students, and does not "prepare students for life" (Stauffer, Heath, Coyne, \& Ferrin, 2012). Some examples of students who have ended their life through suicide due to cyberbullying are Holly Grogan, Megan Meier, and Ryan Halligan. Holly Grogran was a daughter and sister (Bird, 2009). Her world ended tragically on September 16, 2009, by jumping from a 30-foot bridge near Gloucester, UK. She received mean-spirited messages on her Internet Facebook page. She moved to other schools but the messages continued and so did the tormenting until she ended her life. Megan Meier is another example of a teen that ended her life 
due to being harassed and Ryan Halligan was a middle school student who was harassed and took his life due to social media injustice.

\section{Ethical Considerations}

Boundaries and guidelines are extremely important for our well-being. Items such as spying, lying, and exposure of secrets in blogs, Twitter $^{\odot}$ feeds, Facebook ${ }^{\odot}$ status, and updates are allowing private comments to become very public including how social networking sites offer a lot of information about a person. Facebook $^{\circledR}$ pages offers information such as life goals, education history, preferences of hobbies, and many other details. The ethical dilemma is presented in providing this information in a media setting (Moran, Seaman, Tinti-Kane, \& Babson (2011).

Whitehouse (2010) touches on many different aspects of ethical behavior, privacy issues like the differences between what Internet users expect, and what actually exists. Human resources, educators, and others use this information as "sources" and then expose the information to groups of individuals. Some professors/educators use the information in order to share with the class in an ethical manner of what not to do.

\section{Teaching Social Media Applications}

Media literacy is a new key element that all instructors should plan to learn and include in their teaching. Students need to be able to perform $21^{\text {st }}$ century skills in schools in order to survive and thrive in the workforce (Wagner, 2008). The fast pace for technology and the student's role in using social media is transforming the consumer. Facebook ${ }^{\odot}$ and Twitter $^{\odot}$ are reshaping the way that people communicate with each other. It explains how individuals and the

program communicate to all the users. Using Twitter $^{\odot}$ produced richer discussions and provided more opportunities to extend the conversations outside of class (Junco, Heiberger, \& Loken, 
2011). The conclusion is that Twitter $^{\odot}$ can be used to engage the students in academic and psychosocial development (Bruning, Schraw, \& Norby, 2011). According to Papandrea (2012), educators from around the country have successfully integrated various social media platforms into their classroom like Twitter $^{\odot}$ and Facebook ${ }^{\odot}$. The educators are using these programs to help remind students of homework assignments or test dates, improve communication with their students individually and as a class, help with group or team projects and students can continue dialoging about classroom topics outside of class. They have found that shy students are more willing to contribute to class conversations if they can do so anonymously (Papandrea, 2012). Social media helps students with their creativity, plagiarism, intellectual property rights, and the credibility of sources of information, collaboration, writing, and technical skills (Kessler, 2010).

To help educators begin to use social media in classrooms, Shim (2011) discusses in detail many different social media applications. The programs are created to be used in educational processes to incorporate social media into the classroom. Edmodo is a social learning network for teachers and students, showing schools districts some classroom instructions and is similar to Facebook ${ }^{\odot}$. Edmodo includes materials, lesson plans, links, videos, homework ideas, and school notices. SchoolTube, Inc. is the nation's largest video-sharing website for education and is comparable to YouTube ${ }^{\odot}$. The video sharing is for teachers and parents only. Glogster EDU is a program to create posters, mobiles, or dioramas for projects. Collaborize Classrooms is a private on-line community to continue the classroom environment outside of class. It is a place to practice quizzes, create documents, and create videos to help with concepts and homework for students use. EDU 2.0 is also mentioned and it is to teach and learn in an on-line format. Kidblog.org is a site designed for elementary and middle school teachers who want to blog with their students. Ning, Inc. is a social website for fundraising, for 
mobile apps, and website creation. Elluminate is presentation enhancement software for web conferencing. Survey monkey is a survey program that allows educators to create surveys and evaluations. EdSocial Media is a program that is conference and forum based allowing other teachers to discuss topics shared. Technology integration and collaboration in education helps other teachers learn how to use social media in the classroom (Rivero, 2011).

As professionals, teachers are also using social media to help them further their own knowledge and use to connect with other educators to discuss how to incorporate social media in the classroom and keep in communication with family, friends, and other professionals as well as following social media groups that dialog about specific educational issues or classroom subjects (Kessler, 2010).

YouTube $e^{\odot}$

YouTube $^{\circledR}$ is being used in a very interesting way with students in collaborating technology with $21^{\text {st }}$ Century skills. Incorporating how to make a video and uploading it to YouTube $^{\odot}$ is a popular way that students are using social media. Learning how to make a video involves using multiple disciplines in learning such as writing, music, video creativity, graphic design, technology, public relations, copyright, marketing, accounting, sales, website development, layout, graphic design, statistics, mathematics, geography, and working through the process of engaging audience members to watch the video that the individual or group created. Encouraging, tutoring, sharing, and editing allow informal learning to occurring in different realm of $21^{\text {st }}$ Century skills. Some students will watch and make comments on videos created by others, and other students will annotate and remix a video to show the newly created video to others. With the advancement of technology, individuals are able to develop skills that were never even considered in the past. YouTube ${ }^{\odot}$ allows individuals to learn from watching and 
observing what other individuals have done and to build upon that knowledge in their educational. Having proper curriculum and technology capabilities in order to incorporate classroom learning in a life-learning environment is essential. Without either of these two parts, you would not be able to successful incorporate a life learning project that students feel is fun at the same time learning. "Technology allows educators to incorporate innovative ideas into their curriculum. It is fitting for educators to find technologies that make their job more efficient and make the student's learning more engaging" (Cayari, 2011). Television and computers entice students through visual stimulation. Being able to incorporate this type of learning is part of the culture for the $21^{\text {st }}$ Century student.

YouTube $^{\odot}$ has been blamed for cyberbullying and cyber predators. This is just one venue of how bullies and predators gain access to students through their culture matrix. In response, schools have blocked YouTube ${ }^{\circledR}$ to students. Advocates suggest that school districts learn by educating children, teenagers, and adults to achieve digital literacy instead of quarantining them for individuals use in a learning environment (Hartley 2009; Palfrey \& Gasser 2008). This will allow society to better understand and use digital resources such as YouTube ${ }^{\circledR}$ in a learning environment. When new technologies emerge, educators seem to stand either on the side of enthusiasts or on the side of skeptics. "Collins and Halverson (2009) discuss how education in the age of technology needs to be rethought. Educators need to teach students how to acquire this information thus enabling them to become lifelong learners." (Cayari, 2011). YouTube $^{\odot}$ according to Lange (2010) is more a social media site than a video sharing site. Individuals share ideas, gather to discuss ideas, and learn from more experienced individuals who have knowledge to share to those who may be interested in learning about their topic of expertise. YouTube ${ }^{\odot}$ provides an outlet to express their talents to a large audience and receive 
feedback. "Students from across the world can share multi-tracked compositions, art work, videos, and dialog with others." (Cayari, 2011). As education changes, new technologies will become available and as Palfrey and Gasser (2008) stated “tomorrow's popular site may not even be created yet".

Sexting

Sexting occurs when a person takes a sexually-explicit digital photograph of him or herself or of someone else, and sends it via a mobile phone text or message to someone else (Nickel, 2006). According to Nickel (2006), it only takes less than 15 seconds to take the photo and forward it to someone. What most individuals do not realize is that if your child receives a photo and forwards it, they could be charged with a fourth degree felony as a distributor of child pornography and labeled as a sex offender for the rest of his/her life. Peer pressure seems to play a major role in sexting for today's teen. 51 percent of teen girls cited pressure from a guy, and 18 percent of teen boys blamed pressure from girls for taking a photo of themselves and sending it to someone else. It is a second-degree felony and if convicted if processed in court a person could be placed in prison for up to three to five years (Nickel, 2006). This person could be labeled as a sex offender for his/her life if prosecuted and convicted. A critique (positive and negative) of the learning theories Positive

The learning possibilities that are used when integrating social media technologies and activities in a Problem Based Learning approach including factors such as collaboration, student activity, and participation. Students are currently using social media technologies on a consistent basis in a variety of settings and web tools are important from a theoretical learning perspective. How students engage in learning through using the short term and long-term memory are part of 
the four steps of the Problem Based Learning strategy, which consists of the learning process, motivation, infrastructure, and resources. It also provides information concerning the metacognitive process, when students are using social media through procedural knowledge. A reason to perform the comparison in social media instruction is that there has been determined to be a match between current policy and curriculum goals for our modern economy. Another reason for integrating social media into a classroom is that users are able to create and maintain connections between formal and informal learning components while using technology (Gruber, $2013 b, 2013 c)$.

Negative

The data presented concerning the number of hours of social media being consumed by the average teenager and how they use the social media technologies is seen as a negative. The negative connotations with using social media such as sexting, cyberbullying, and addiction tendencies are also apparent (Kessler, 2010). The drawbacks also include incorporating social media in the classroom from a technology advancement and educational perspective. Some examples given are the lack of teacher training, no set process for evaluation purposes, the individual's ability to use social media technology, and how the educator actually feels about the social media technology process by being comfortable in using social media personally and professionally.

Bynum (2011) was very negative on teachers who are not willing to become social media savvy, and described how digital technologies and media literacy education lacks a focus and provides confusion in this area for educators, administrators, and students. Some educators do not have a clue about even how to begin to use this platform in their teaching environment. The article overall was not beneficial to social media integration until the parameters of the media 
literacy area are explored, and written for the average educator to understand and comprehend how to integrate this process into their classroom.

\section{Research Section}

\section{Social Media Technology}

The research topic is new to the education world, since social media was recently created, and is rarely implemented in private Christian high school classrooms or in public high school classes (Whitehouse, 2010). Most research conducted is at the collegiate level incorporation (Hung \& Yuen, 2010). The topic of incorporating social media technologies in education could be beneficial for high school students. Social media technology may make a difference in how students learn and engage in a high school and in a college classroom environment.

\section{Statement of the Research Problem}

Do students use social media in a private Christian high school? Which social media applications do they use? How are the students using social media? The research completed to compile the literature review displays a majority of positive influences in the collegiate level, and I am trying to determine if using social media technology in a high school educational classroom would increase learning.

Social media is becoming a society norm that individuals participate in on a regular basis. Incorporating social media and technology skills as classroom tools allows individuals to use their God given talents to improve their own knowledge as well as better society. Teaching social media technology in the classroom under proper instruction by an educator allows students to be trained in technology. Students in developing their potential and abilities for future roles may receive beneficial learning by using social media components. Using social media in negative connotations such as cyberbullying, or not using the technology in a beneficial way, can cause 
difficulties for educators and educational institutions. As research demonstrates, education is essential to incorporate social media technologies since it is becoming part of an everyday occurrence for the students (Rivero, 2011; Levy, 2010; Madhava, 2011; Lin, Hoffman, \& Borengasser 2013, Shim, 2011, Whitehouse, 2010).

Purpose of the Study

The purpose of this study is to investigate in a private Christian high school student use of social media utilizing qualitative study instrumentations of a questionnaire and a face-to-face interview process to determine if social media could influence learning in a private Christian educational classroom in high school. Previous collegiate research indicates that the majority of professors incorporating social media technology in educational classroom assignments enhance the learning of students and their knowledge (Rivero, 2011; Levy, 2010; Madhava, 2011; Lin, Hoffman, \& Borengasser 2013, Shim, 2011, Whitehouse, 2010). Schools teach how to be independent in performing academic assignments, and they provide opportunities for achievement and failure. One purpose of the educational system is to teach knowledge, special skills, and attitudes that positively contribute to society. Technology instruction allows learning objectives to be divided into specific components and the students need to learn these components in order to advance their knowledge for $21^{\text {st }}$ Century skills. Educators are held responsible for student learning until their students have shown that they have mastered the learning objectives (Wagner, 2008). STEM stands for Science, Technology, Engineering, and Mathematics and represents a program that is an approach to education to revolutionize the teaching of mathematics and science by incorporating technology and engineering into regular curriculum by creating a "meta-discipline" (Fireollio, 2014). Typical teacher-centered classroom is changing to incorporate a curriculum that is driven by problem-solving, discovery, exploratory 


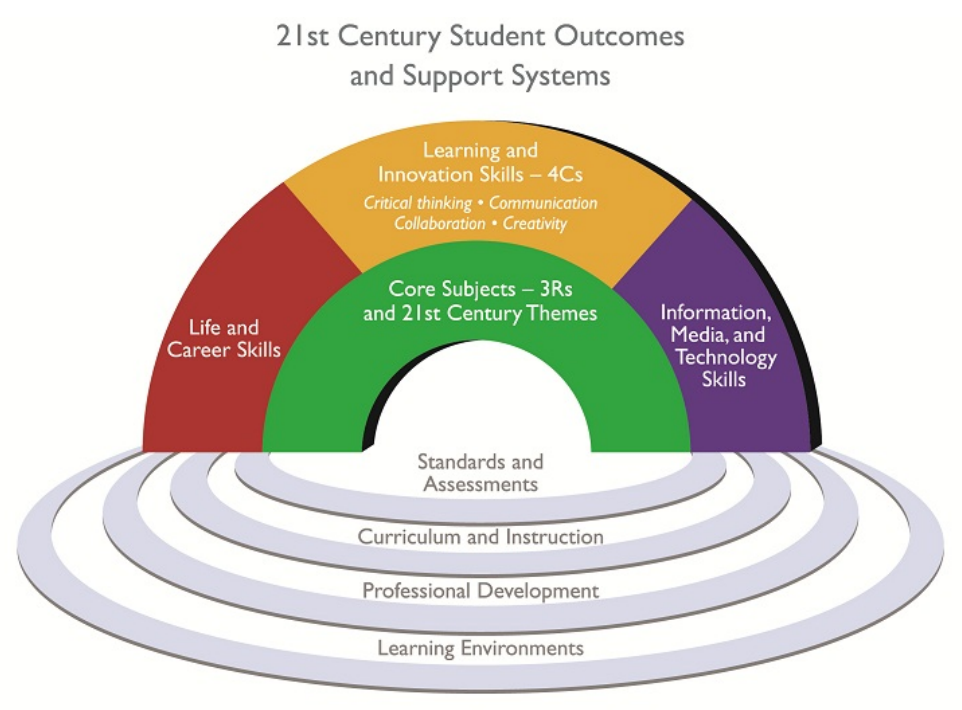

Partnership for 21st Century Skills: Framework for 21st Century Learning learning, and require students to actively engage a situation. The four topics of STEM have been taught independently and by changing the curriculum, it allows individuals to teach in an innovative way to problem solve and have the learning

opportunities expanded. "Programs that are usually reserved for college-level classes such as Figure 1.21 ${ }^{\text {st }}$ Century Components, Partnership for $21 \mathrm{st}$

computer animation and CAD programs are being implemented in high school classrooms across Century Skills (2014). Washington, DC

the country as part of the STEM education initiative" (Fireollio, 2014). STEM educators focus Graphic displays the area of skills and the layers within

on $21^{\text {st }}$ Century skills in their courses and provide excellent opportunities for students to master the $21^{\text {st }}$ Century skill sets essential for student learning.

core subjects, innovation, technological literacy, and life and career skills. STEM educators

provide students with the skills to think critically, communicate, and assess the information

presented in all of the learning endeavors. STEM educators use the students' facility with

technology to their advantage by developing lessons that are hands-on, real world, and collaborative (Jones, 2014).

Teaching students how to incorporate technologies, not only in a private Christian high school classroom, but also as part of the essentials of living, allows educators the opportunities to provide instruction, concerning ethical and moral issues in using social media technology.

Students seem to understand the concept of social media technology, and are willing to incorporate the latest technology as part of their regular Christian lifestyle. The class domination or the economic gap differences occur when different cultures are not able to purchase the latest 
technology for students. Children are taught computer basics as early as kindergarten. In the Midwest, keyboarding/typing is usually not provided formal instruction until the students reach the middle level years. However, students can receive social media technology from some Christian families very early in life. Students utilize cell phones so that they can socially connect with their family and friends. Teaching how to use social media technology in the classroom provides the opportunity for instruction in a setting that allows for discussion and teaching in a safe environment (Lin, Hoffman, \& Borengasser, 2013). Proactive classroom management strategies that incorporate positive behaviors include class structure, define expectations of students in class, provide positive feedback, and encouragement to reach the goals established. Reinforcing these classroom management strategies is important for the structure of learning in a technology environment (Latta, Thompson, Ruthmann, \& Thibeault, 2012). Instructors should consider not only teaching how to use the technical aspect social media applications correctly. Instructors need to explain the importance between good and evil use of social media. Some good uses of social media would include the ability to expand the learning opportunity outside of class and connecting to individuals from around the world to expand knowledge of other countries and cultures. The ability to connect through communication to other family members and friends by sharing photos, videos, and updates about what is occurring in their life is a good reason to connect via social media. Some evil use of social media would consist of the cyber predators that prey on individuals who use social media, the addiction that can occur, sexting, and cyberbullying.

Educational development allows growth in cognitive learning and in knowledge (Piaget, 1983), social skills (Levy, 2010), attitudes (Madhava, 2010), and moral values (Bruning, Schraw, $\&$ Norby, 2011). Piaget's theory of cognitive development states that students have to construct 
and learn through participation in relating to objects and in social relationships (Piaget, 1983). Using social media in class allows students to use the activities to expand and enhance their learning knowledge (Lin, Hoffman, \& Borengasser, 2013). Here are some ideas on how you could incorporate social media instruction into educational learning opportunities. Some strategies of integrating social media into an educational classroom in a public or private Christian High School would include create a twitter account, start your own blog, subscribe to other blogs, use social bookmarking services, add your life streaming, share your links, comment on other blogposts, follow interesting people or groups, start a wiki, publish a video, try new tools before deciding whether or not they are useful (Camacho \& Guilana, 2011). Student blog posts are often from their own personal interest rather than one a specific topic for a course. When students blog and read and respond to other students' blogs, a network of interactions occurs and this is what occurs during social media use. It is a great way to teach the concept in a controlled environment (Camacho \& Guilana, 2011).

School districts can use social media to connect with parents and the community. Some districts are using social media communication to tell the story of successful learning objectives of the students who attend their school. This provides a venue to reach the community to encourage participation in levies, school functions, and to draw people to the school district to enroll their children. Photos of students learning showcases school activities in a positive manner (Gordon, 2012). A schools website must go beyond providing information to facilitate interaction. It must be easy to access the staff, but posting surveys, leaving a spot for comments, and venturing into social media is a plus for those in that community. "At least one tweet a day is posted on Twitter ${ }^{\odot}$, ranging from cafeteria menu to news on a spelling bee, to showing and sharing a 'good news' story on Facebook ${ }^{\circledR}$ and inviting public comments are ways that Klein 
School District is reaching the community with news" (Gordon, 2012). Anti-bullying training program for teachers or description of specific classes are other ways that some school districts are using social media to engage the community. Videos are also becoming popular on websites as schools incorporate video classes and optimize their webpages for mobile devices and apps that enable users to access information from their phone. Targeting specific groups within the community such as pre-school parents, or alumni, or local businesses via social media are other ways that schools are using social media to engage the community.

\section{The Research Question}

The research question chosen is "How are Christian teenage students using Social Media and what are the implications for private Christian education?" The question is broad enough to incorporate a wide span of social media influences such as Twitter $^{\circledR}$, Facebook $^{\circledR}$, YouTube $^{\circledR}$, Google $+^{\odot}$, Instagram ${ }^{\odot}$, and LinkedIn ${ }^{\odot}$. The answers to the question provides information educators and students can use to hold open dialog concerning how these tools could affect educators learning through teaching social media and with the students own learning process.

\section{Method}

\section{Participants}

The participants for this research project consisted of current high school students from my seven classes, who I taught second semester at Cuyahoga Valley Christian Academy (CVCA) (a private Christian High School) in 2014. All attend CVCA (a private junior high and high school of 850 students). The Internet policy for CVCA includes what individuals can and cannot do as part of our educational process and explains how educators can choose to communicate via Facebook $^{\odot}$ and Twitter $^{\odot}$ to students (See Appendices D). A sample of $13 \%$ of the junior high and high school Christian population participated at Cuyahoga Valley Christian 
Academy and 24 individuals were interviewed out of the 109. I personally interviewed these 24 students (See Appendices A and B for questionnaire and interview questions). The sample of students, out of the 850 students, who completed the questionnaire, was 109 students $(n=117)$. 117 students were offered the questionnaire to participate. Eight students did not complete the questionnaire. Seven of these eight students were seniors and chose not to complete the questionnaire due to the timing of the questionnaire (it was the last day of their classes and they were either absent that day, or had to complete other assignments for their grade, and did not have time to complete the questionnaire). One of the eight students was a sophomore and she did not complete the questionnaire due to non-parent approval. All the other 109 students completed the questionnaire with parental permission (see Appendices C) and they did not receive any type of compensation (points, extra credit, financial gain, or rewards) for completing the questionnaire.

The demographics of the high school students included ethnicity, gender, and age. The ethnicity

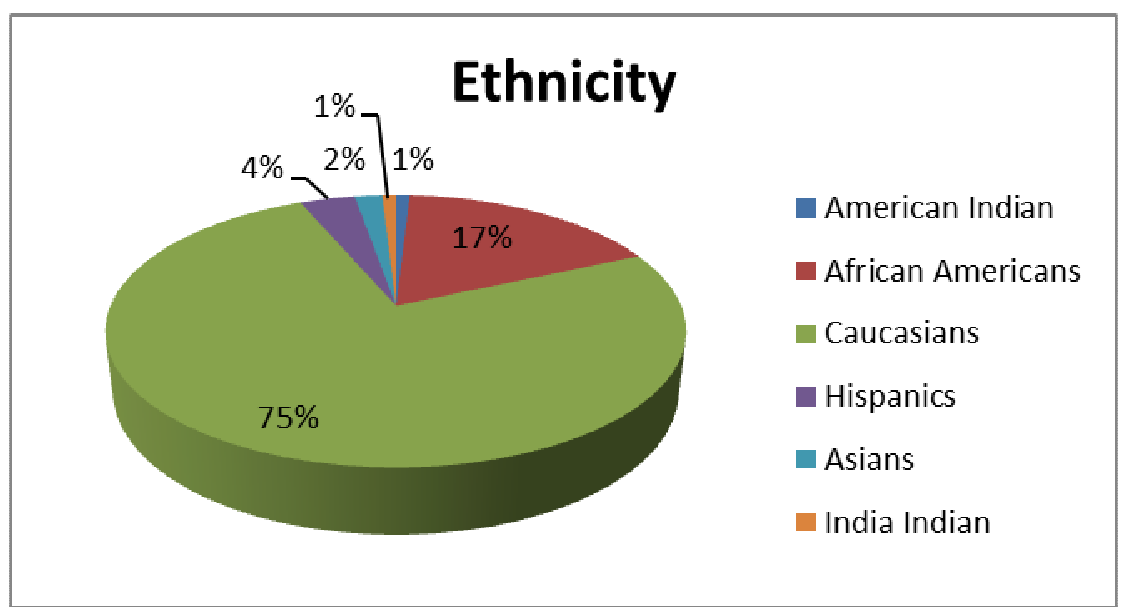

Figure 2. Ethnicity Graph displaying the variety and number of individuals who were participants in the study. Beavers, $\mathrm{K}$. (2014, May 15). Participants Ethnicity Statistics. Cuyahoga Falls, $\mathrm{OH}$ of the students was one American Indian, 19 African Americans, 82 Caucasians, four Hispanics, two Asians, and one India Indian.

There were 62 students in the age category of $12-16$ years old $(57 \%)$, and 47 students in the age category of $17-18$ years old 
(43\%). Given the focus of the present study on social media technology, the participants' respective background information was collected to provide a more informed understanding of their social media technologies experiences. All the participants reported that they were comfortable learning with computers and technologies in and out of class. The majority of the participants was experienced in web-based social media technologies (e.g. Twitter ${ }^{\odot}$, Facebook ${ }^{\circledR}$, YouTube $^{\odot}$, Google $^{\odot}{ }^{\circ}$ Instagram $^{\odot}$, and LinkedIn ${ }^{\odot}$ ) and was members of more than one social network prior to participation in the present study. Of the participants, $56(51 \%)$ were male and $53(49 \%)$ were female.

The following chart shows the hours per week that students are engaged on social media

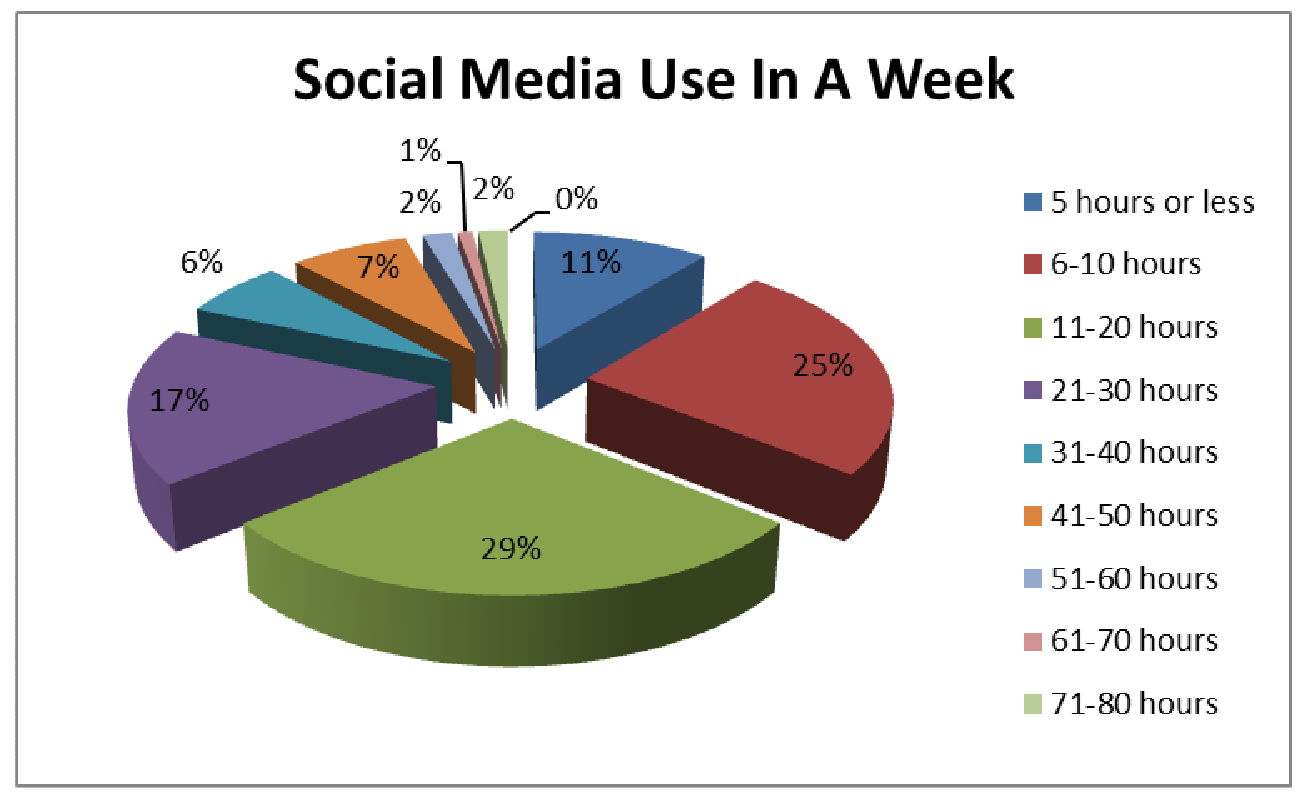

Figure 3. Participant results of how often they use social media during the week from the statistical data gathered from the Social Media Questionnaire responses. Beavers, K. (2014, May 15). Social Media Used for in a Week Statistics. Cuyahoga Falls, OH programs and/or the Internet from the questionnaire data gathered. Most of the students were engaged for approximately six to thirty hours per week. Only a few were on the Internet and involved with social media in abundance. Individuals who are on the social media programs for any length of 
time may be showing that they have an addiction to social media. As you can see, the majority of students spend 11 to 20 hours per week using social media technologies.

By researching a sample of the population to determine which social media technologies the students are familiar using and, as well as how they use this technological tool, would allow me to present the findings to the CVCA administration and school board stating why we should incorporate social media into the technology curriculum instruction to our students. Currently only two instructors out of 66 are using these types of social media tools at CVCA. The instructors teach Economics and Government to eleventh and twelfth grade high school students in a private Christian high school, and were interviewed separately from the student interviews. When interviewed, they both stated, "we are preparing college preparatory students to have knowledge on how to use this tool in their collegiate career and work venues" (Peters, \& Ling, 2014). This relates to the research completed by Lin, Hoffman, \& Borengasser (2013) who state that they find instructors at the collegiate level extending their teaching time by using social media outside of the allotted class time.

\section{Instrumentation}

A survey instrument was used as the primary data collection for the study and was administered during the final week of classes during the second semester at CVCA, May, 2014. The survey was provided in paper-based format along with face-to-face interviews, having the same questions given to all participants who were selected for the interview process. (See Appendices B). 


\section{Questionnaire Development}

The questionnaire was developed by the following means. The background for the questionnaire development began with my knowledge of the participants for my research project who were my current students attending Cuyahoga Valley Christian Academy during second semester. All students in my seven classes will be selected to participant in the study. They are not part of a vulnerable population. The students are between the ages of 13 and 19 years old. The risks associated with the study is very minimal. The risks would be the time commitment to be interviewed and to answer questions from the questionnaire.

I used a pilot test of 20 students to determine if I was asking coherent questions that the students understood and if I was able to receive the information that I wanted to learn from their answers to the questions asked. After three revisions, I came up with the social media questionnaire at the end of this document (see Appendices A). All the students gave permission to participate along with their parents, except for one, and I sought out administration permission as well in order to conduct the questionnaire and interviews. The students for the interviews were selected from my class list due to not having final exam second semester. The majority of these students in the interview process were seniors since they have taken the elective courses in their high school schedule. No inducements were provided for being interviewed.

\section{Personal Bias}

The bias that needs to be addressed would be that this sample was from one school, a Christian high school, and was a small sample of the larger population. Since I teach technology, I am also biased on trying to implement this new technology into the classroom environment. I am also part of the technology team that conducts the annual survey on cyberbullying information from all junior high and high school students. I record and provide 
data in graph and chart form to the administration concerning the responses from the students on cyberbullying. I believe that incorporating technology that the students use would help them become more engaged in learning environments. However, the engagement of learning needs to be educational, purposeful, and appropriate for all students. Teachers need to make sure that educators are not excluding any student in a learning environment. Teacher training would have to be taught to educators in order for them to understand and comprehend how to use the social media technology as well as what the capabilities of the social media technologies can do.

The questionnaire was broken into three sections. Section I was the name and type of the Internet connection that the participants use as a primary way to connect to the Internet. Section II was on their current social media usage and Section III was on the demographics of the participant. Qualitative data from the open-ended survey items were content analyzed to provide more in-depth information in the student's voices. To enhance the trustworthiness of the survey instrument, the student's participation in the interviews, served as secondary data sources, and was used to supplement the survey results. I was the only person who entered the data, saw the answers that the students provided during the interviews, and I created the formulas and graphs used in this report. I also checked the data entry numerous times for correct recording of information.

\section{Procedure}

I began the process with creating the research project proposal. After completing the research proposal process and questionnaire implementation and receiving permission from Dr. Stephen Gruber, Dean of Education, at Cedarville University to submit to the Institutional Review Board for approval, I received permission from the Institutional Review Board of Cedarville University on May 1, 2014, to implement the research proposal. I met with the 
principal of CVCA, Mr. Michael Bova, on May 2, 2014. During this meeting, I provided the questionnaire, interview questions, and the email/parental permission slip I was going to send to the student's families that I teach asking for participation. After reviewing the material, he granted permission for me to proceed. I sent the email and parental permission slip (see Appendices C) to the parents explaining that I was conducting research and asking them to complete the parental permission slip and return it to me by May 10, 2014. I received 99.9\% approval from the parents and the students to participate in the study. One family chose not to have their child to participate in the questionnaire. This child was not penalized for not participating. I provided the questionnaire to all students on Friday, May 15, 2014, (last day for seniors). The other students would begin semester exams on the following Monday. It was the day that I have the students complete questionnaires for my classes at the end of each semester. I had the students complete three questionnaires. The three questionnaires completed were a course evaluation questionnaire for the administration at CVCA, the research questionnaire on social media (see Appendices A), and an evaluation form on the instructor for this past semester for my personal learning evaluation process. No compensation of any kind was granted for completing the questionnaires. I did not give out extra credit points, points for completion, or any financial gain nor did they receive any type of reward. I gathered the questionnaires by classes and brought them home to process. I sorted the three questionnaires into their own sections not keeping track of who was in what class. For the research questionnaire, entering the data took approximately 15 hours to type in the data into Microsoft Excel for the 109 participants. Each question and all 109 answers were typed in a separate worksheet in a single workbook entitled "Research Data for Social Media". I used the formula of =CountA to add the x's for the student's responses. I also used =SUM to add each of the total responses by category together to 
ensure that I had 109 answers for the students on each worksheet. I also tripled check the data entry for accuracy.

The four questions that provided the most information were "What types of social media are used for school?" "What types of social media are used for personal use?" What is the primary reason for using social media networks? and "In which of the following social media networks do you have a personal profile?"

\section{Face-to-Face Interviews}

After having the students complete the questionnaire, I interviewed students in the Web Design class, the Leadership class, and the Business Entrepreneurship class during the week of Monday - May 18 through Thursday - May 21, 2014, because they do not have to complete a final exam for the semester. I have 12 students in my Business class, eight students in my Leadership class, and eight students in my Web Design class. I have four students who are enrolled in more than one of these three classes and I did not interview them twice so that I would not duplicate their responses. During class time, the students worked on final projects independently, while I asked the following questions to a high school student individually.

The setting for the face-to-face interviews was private. I did not want the other students to hear what the interviewee was stating about his/her personal social media use. The interviews were held in my classroom office. I sat at my desk and the students sat in a comfortable chair across from my desk. I began each interview in the same way, I thanked them for giving me a few minutes of their time and explained that I was conducting research (all of them know that I am involved in furthering my education at Cedarville). I began the interview with having the students tell me about their computer usage, social media programs, and some of their favorite tweets. I also asked them to tell me one person that they follow in Twitter ${ }^{\odot}$. I was surprised at 
the number of students who follow business people like Warren Buffet, Jack Welch, Bill Gates, or Dave Ramsey (Financial Instructor). After asking the questions, I thanked them, had them return to the classroom, and asked the next student to come and answer questions. My classroom and office connect so while the students were interviewed, I was able to look out of my office window to ensure that the other students were working while I was talking to the individual student. I took notes from each interview and used the student's initials to determine who answered what. I transcribed the notes using my home computer that weekend (May $23-25$, 2014). I had participant feedback by having the participants review their interview notes from their actual interviews for clarity and accuracy purposes. The interviewees reviewed the participant feedback during the week of May 25, 2014. All changes were incorporated into the notes for future reference.

The questions used for the face-to-face interviews were the same for all candidates. The standardized open-ended interview questions included the following "Are you comfortable using computers?" "Do you participate in social media technologies?" "Please tell me some of your favorite tweets? Whom do you follow on Twitter $^{\circledR}$ ? What social media applications do you use on a regular basis?" I then asked, "How often do you use social media on a daily basis - a few minutes, about an hour, less than four hours total, or between four and eight hours total?" I choose 4 hours and eight hours due to attending school for 8 hours, sleeping for approximately 8 hours, will leave approximately 8 hours of being awake and providing the opportunity to use social media. Another question I asked was, "Why do you feel that social media is a good method to stay connected to family and friends?" The last question was, "Do you feel if educators incorporated social media in their classes you would learn more and be more engaged and why?" 
I also interviewed the two instructors who are incorporating social media components in their classrooms at CVCA from the questionnaire responses. The instructors are using these tools in an effective classroom management component to expand the communication of learning outside of the established class time and to have the students continue learning about governmental and economic issues (Peters, and Ling, 2014). This relates to the research and articles written by Lin, Hoffman, \& Borengasser (2013).

\section{Findings/Results}

The most interesting component of this research project was finding out which of the social media networks that high school students are actually using. Facebook ${ }^{\circledR}$ is their primary social media program, followed by Twitter $^{\odot}$, and Instagram ${ }^{\odot}$. When starting this process, I thought the high school students used only Facebook $^{\circledR}$; however, I realized from the small sample they use and prefer Twitter $^{\odot}$ and Instagram $^{\odot}$ over Facebook $^{\odot}$ from the sample taken. Having had the statistics for the past few years on cyberbullying from the annual survey taken of all students who attend CVCA also provided me with some of the background of social media use and who is involved with the cyberbullying issues. The demographics provided me with basic information on the participants. For educational purposes, students are using YouTube ${ }^{\odot}$ and Google $+{ }^{\odot}$ currently from the data received from the questionnaires. 


\begin{tabular}{|c|c|c|c|c|c|c|c|c|c|}
\hline $\begin{array}{l}\text { In which } \\
\text { of the } \\
\text { following } \\
\text { social } \\
\text { media } \\
\text { networks } \\
\text { do you } \\
\text { have a } \\
\text { personal } \\
\text { profile? }\end{array}$ & Facebook $^{\circledR}$ & Google+ & Linkedln $^{(}$ & Myspace ${ }^{\odot}$ & Flickr ${ }^{\circ}$ & Twitter@ & $\begin{array}{l}\text { Stumble } \\
\text { Upon }\end{array}$ & $\begin{array}{l}\text { Snap } \\
\text { fish }^{(}\end{array}$ & Instagram $^{(}$ \\
\hline & 81 & 35 & 15 & 1 & 0 & 67 & 2 & 2 & 64 \\
\hline
\end{tabular}

Figure 4. Social Media Networks Participant information concerning the number of profiles students have in social media currently. Beavers, K. (2014, May 15). Social Media Personal Profiles Statistics. Cuyahoga Falls, $\mathrm{OH}$

Students in the sample also mentioned Google $+{ }^{\odot}$ because of the push at our school to use this social media program for Hangouts, documents, and Google $+{ }^{\circledR}$ drive due to the inexpensive venue compared to Microsoft ${ }^{\circledR}$ Office. For school related activities, the students use the

\begin{tabular}{|c|c|c|c|c|c|c|c|}
\hline \multicolumn{8}{|c|}{ Personal Reasons for Social Media } \\
\hline $\begin{array}{l}\text { How } \\
\text { frequently } \\
\text { do you use } \\
\text { each of the } \\
\text { social } \\
\text { media } \\
\text { applications } \\
\text { listed } \\
\text { below for } \\
\text { personal } \\
\text { reasons? }\end{array}$ & Daily & $\begin{array}{l}\text { A few } \\
\text { times } \\
\text { each } \\
\text { week }\end{array}$ & $\begin{array}{l}\text { Once a } \\
\text { Week }\end{array}$ & $\begin{array}{l}\text { A few } \\
\text { times a } \\
\text { month }\end{array}$ & $\begin{array}{l}\text { Once a } \\
\text { month }\end{array}$ & $\begin{array}{l}\text { Less } \\
\text { frequently } \\
\text { than once } \\
\text { a quarter }\end{array}$ & Never \\
\hline Facebook $^{\circledR}$ & 32 & 27 & 9 & 9 & 3 & 2 & 25 \\
\hline Google+ ${ }^{\circledR}$ & 12 & 34 & 9 & 4 & 0 & 1 & 45 \\
\hline LinkedIn ${ }^{\complement}$ & 3 & 5 & 2 & 0 & 2 & 0 & 90 \\
\hline Twitter@ & 56 & 9 & 1 & 1 & 0 & 0 & 39 \\
\hline YouTube $^{\circledR}$ & 26 & 42 & 14 & 4 & 1 & 0 & 21 \\
\hline Instagram ${ }^{\circledR}$ & 9 & 0 & 1 & 0 & 0 & 0 & 0 \\
\hline
\end{tabular}


Figure 5. Personal Social Media Technology Used for students own personal pleasure on the different social media venues. Beavers, K. (2014, May 15). Social Media Used for Personal Reasons Statistics. Cuyahoga Falls, OH.

following programs on a consistent basis. The data demonstrates that high school students are using Twitter $^{\odot}$ as the primary social media technology personally. Instagram ${ }^{\odot}$ was also popular and not listed on the original questionnaire. Out of the 109 students, 138 students stated that they use social media on a daily basis for personal reasons (due to having multiple accounts); yet only 40 students mentioned that they use social media for educational purposes in just two classes, Economics and Government.

\begin{tabular}{|c|c|c|c|c|c|c|c|}
\hline \multicolumn{8}{|c|}{ Social Media Applications } \\
\hline $\begin{array}{l}\text { How frequently } \\
\text { do you use each } \\
\text { of the social } \\
\text { media } \\
\text { applications listed } \\
\text { below for } \\
\text { work/professional } \\
\text { reasons (school)? }\end{array}$ & Daily & $\begin{array}{l}\text { A few } \\
\text { times } \\
\text { each } \\
\text { week }\end{array}$ & $\begin{array}{l}\text { Once a } \\
\text { Week }\end{array}$ & $\begin{array}{l}\text { A few } \\
\text { times a } \\
\text { month }\end{array}$ & $\begin{array}{l}\text { Once a } \\
\text { month }\end{array}$ & $\begin{array}{l}\text { Less } \\
\text { frequently } \\
\text { than once } \\
\text { a quarter }\end{array}$ & Never \\
\hline Facebook $^{(}$ & 2 & 8 & 1 & 0 & 3 & 0 & 94 \\
\hline Google+ ${ }^{\circledR}$ & 13 & 26 & 4 & 4 & 2 & 0 & 60 \\
\hline LinkedIn ${ }^{\circledR}$ & 3 & 1 & 2 & 1 & 0 & 0 & 101 \\
\hline Twitter@ & 9 & 6 & 1 & 1 & 2 & 0 & 90 \\
\hline YouTube $^{\circledR}$ & 8 & 25 & 4 & 4 & 4 & 0 & 62 \\
\hline Instagram ${ }^{\odot}$ & 5 & 0 & 0 & 0 & 0 & 0 & 1 \\
\hline
\end{tabular}


Figure 6. School Social Media Technology Used at school from the participants responses of the social media questionnaire. Beavers, K. (2014, May 15). Social Media/Internet Applications Used for School. Cuyahoga Falls, OH.

A majority of the students use Google ${ }^{\circledR}$ as the primary search engine, and only 19 out of the 109 have ever used social media to purchase something online. The majority do not use the social media tools that are part of the program(s). The majority of the students use cable (67) to connect to the Internet at home. DSL and Wi-Fi were tied at 21 . The majority of the students stated (96 out of 109) that they have 100+ friends in their social media site profiles.

The primary reason for using social media was to communicate and keep in touch with family and friends (90); to meet new people (13); find old friends (18), make new business contacts (5), keep in touch with current business contacts (5), share pictures, videos, and games (56), promote business (1), and promote ideas (13). When asked again why you use social media for personal reasons communication (104) was the key reason, and networking (40) and news (38) were in second and third place. Here is the information in visual form.

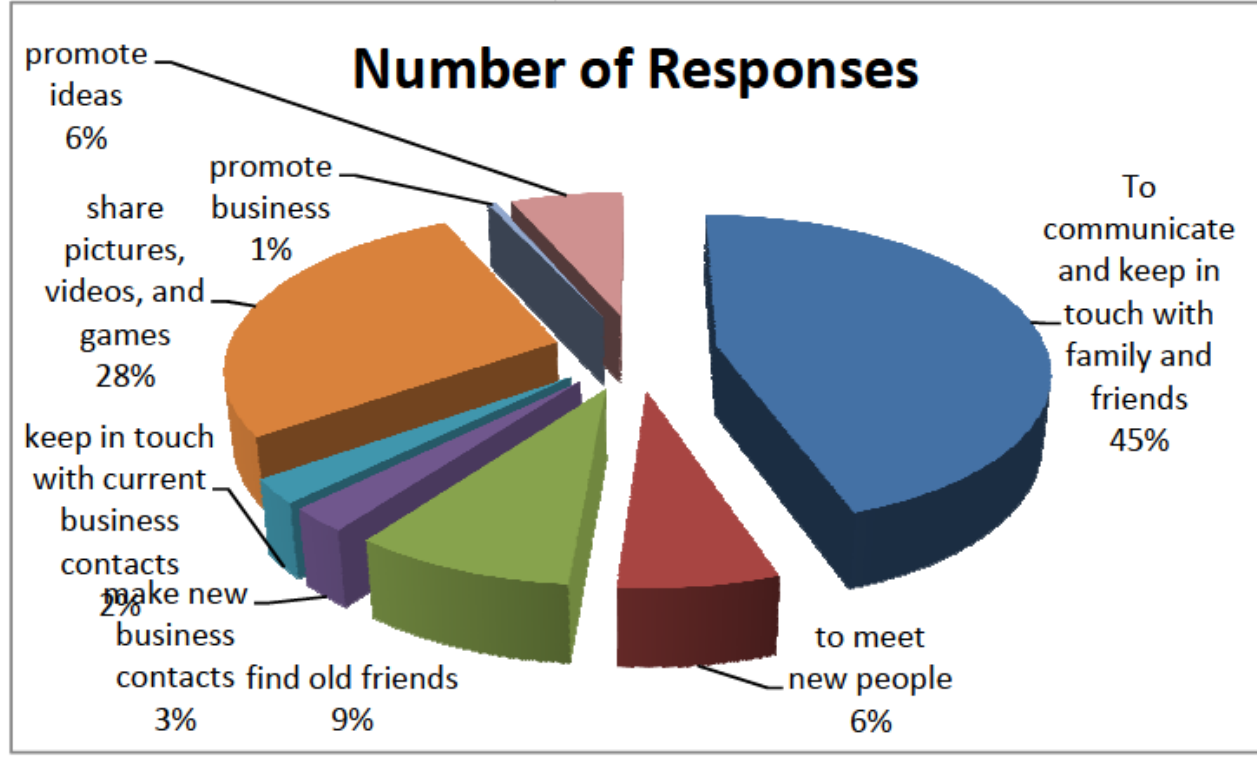

Figure 7. Reason for using Social Media from the participants'
To some of the students social media is very important (25), somewhat important (49) and neither important or unimportant was

responses from the social media questionnaire as to why they use social media currently in their everyday life. (2014). Beavers, K. (2014, May 
ranked third (28). Only four stated that social media was unimportant to them. The students value receiving and sending information via social media (70) and 33 like receiving information only.

Another surprise for me as the researcher was the number of hours that students spend on the Internet. Only 12 students said that they were on the Internet less than 5 hours a day. Majority of them are on for 11-20 hours (31) or 6-10 hours (27) on average. Here is a visual of

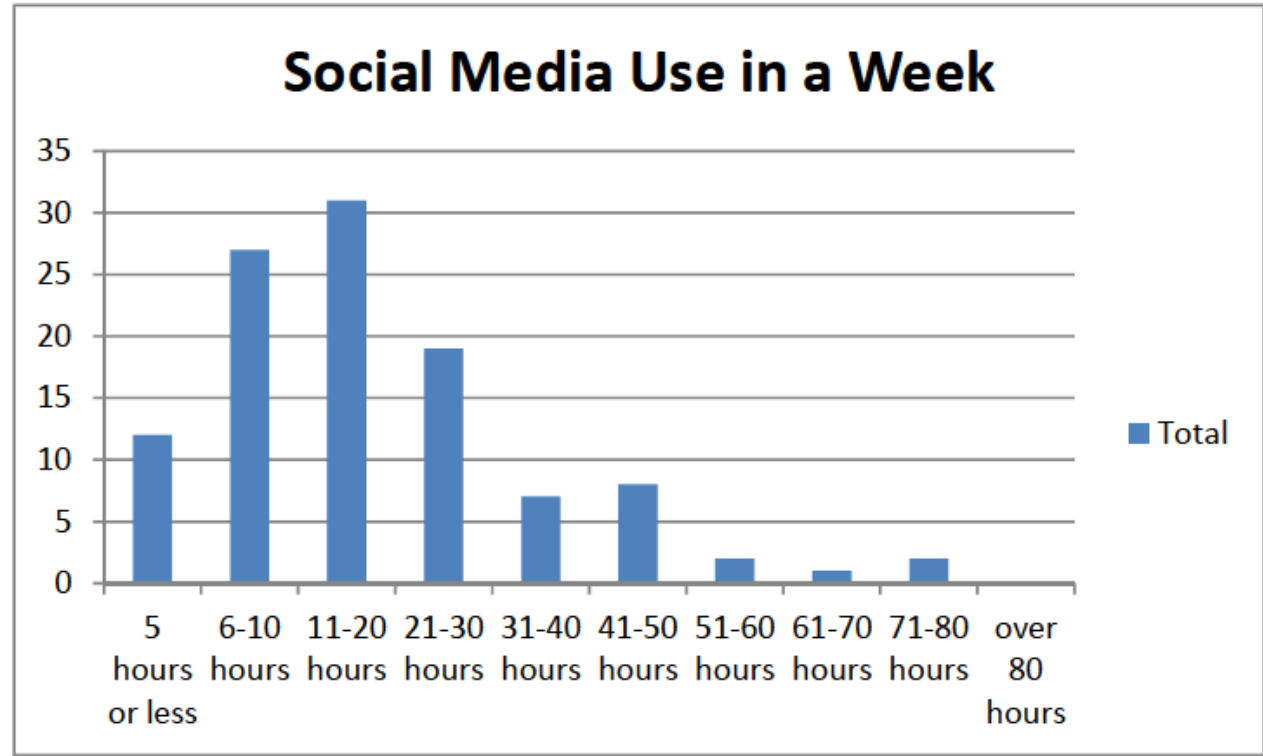

Figure 8. Participants hours of Use in Social Media/Internet in a week gathered from the participants responses. (2014), Beavers, K. (2014, May 15). Social Media/Internet Use for a Week. Cuyahoga Falls, OH. the data gleaned.

The interviews provided additional insight. In one interview, a student made the comment that using "Social media would be so cool if teachers would use it for us to be able to learn." Another student

made the comment that they would set up their own profile for school use only so that students and teachers could not see what they say on their "real" profile. Most of the 24 students were very open to the idea of using social media technologies in the classroom. Their older siblings are using it in college (Lin, Hoffman, \& Borengasser, 2013; Fewkes \& McCabe, 2012; Dean, 2009) and they feel that it would be beneficial as long as it is "not a dumb assignment". Another 
student shared that they believe this will become the future and that schools need to adapt to this concept now and not become behind in teaching 'how to' skills for future use. The students shared some interesting people that they are following on Twitter ${ }^{\odot}$ such as Jack Welch, Warren Buffet, Dave Ramsey, and Bill Gates. One of the tweets mentioned by a student was "control your own destiny or someone else will'. Speaking with the 24 students was encouraging because they stated that there is a need that the educational system can address.

\section{Discussion}

Because social media is so prevalent in our society, much more research needs to be completed in this area. Student learning styles have changed, teaching styles have changed, and the curriculum needs to change to adapt to these changes (De Abreu, 2010). Learning the traditional subjects should not be deleted; however, traditional subjects can be integrated with a focus on technology and especially a social media component (Wagner, 2008). Some research has been done at the collegiate level as the literature review section demonstrated (Rivero, 2011; Levy, 2010; Madhava, 2011; Lin, Hoffman, \& Borengasser 2013, Shim, 2011, Whitehouse, 2010).

How students should be introduced to social media in a classroom environment is something that will require further research, but the research is severely lacking when it comes to pre-collegiate students. Some interesting ways of engaging students have been shared in the literature review section from creating a video and posting on YouTube ${ }^{\odot}$ to incorporating school websites to include social media to the community as well as providing opportunities for multiple disciplines (STEM) to work together to collaborate learning about social media integration. Integrating social media into the educational curriculum can be beneficial for learning environments. Educators are teaching students life skills that can be used for the rest of 
their lives. Educators need to offer opportunities in our classrooms for students to serve other students or the instructor in private classes or in public classes. As the articles stated, most of them were positive or provided guidelines and directions on how to incorporate social media in a safe learning environment. Only one was negative and that was due to the parameters of the assignment being vague and unclear. Developing curriculum that teaches teachers how to develop social media in the classroom would be beneficial (Whitehouse 2010; Levy, 2010; Shim, 2011).

Teachers, administrators, and students should consider the purpose of incorporating social media technology into the curriculum. As teachers embrace this type of technology, by learning and educating themselves, and learn how students are using social media currently, they are more likely to adopt the concept of teaching social media technology in the classroom. Students know and understand this technology intimately and are ready to integrate it into their lives in an educational setting (Lin, Hoffman, \& Borengasser, 2013). Teacher training has to be developed in order to communicate to students the process of integrating social media to the classroom. In-service training needs to be conducted on how to use social media and the benefits of using social media in the classroom. The teachers should not incorporate social media unless they see the value of engaging students using these tools. Social media can be extremely effective tool when used correctly. Policies need to be developed, implemented, and integrated that allows the use of social media to further engage students. All involved in the social media technology should establish boundaries for educational purposes. Educators need to protect oneself and not communicate to students privately, but publically, so that others can see what is said or written. Educators need to be above reproach in all actions, so that individuals would not be found negligent in teaching on this subject. Policies would need to be developed to include 
social media in the educational setting at the junior high and high school level establishing clear boundaries (Madhava, 2011; Shim, 2011; Levy, 2010; Whitehouse, 2010). The policies should prohibit use of district networks, personal communication devices, and digital image devices to engage in cyberbullying anywhere on school grounds or within the area where schools have a legal responsibility for student safety. The annual separate survey taken from CVCA shows students are involved with cyberbullying issues and with social media. The policy must be individualized to meet the need of each individual school and provide an anonymous report box for reporting inappropriate behavior. Supervision of students by adults in using computers and communication-based technology should also be part of the policy. Prevention/Intervention programs are also critical in established a policy. Curriculum based programs incorporating the direct teaching of core values; predictive empathy, peer norms, peer intervention, and netiquette are also beneficial in educating the students, staff, and parents about social media policies (Miller \& Hufstedler 2009).

As educators, the opportunity to guide, direct, instruct, and allow students to use technology in a controlled environment is essential. Students enjoy visual stimulation and are drawn to social media sites that incorporate this feature such as Instagram $^{\odot}$, Facebook ${ }^{\odot}$, and YouTube $^{\odot}$. From the findings, you see that students are using these types of social media more often than those social media sites that just offer writings. Students enjoy sharing videos, photos, or graphics as this was one of the main purposes from the responses provided from the findings of the questionnaire on social media reasons for use. Developing curriculum and lessons that incorporate social media provide knowledge in a safe environment. Teaching students how to tweet or how to communicate via Facebook ${ }^{\odot}$, or any of the social media programs, allows them to expand their knowledge and at the same time analyze how they could build up their neighbor 
via communication skills. Having the students tweet a response or use another social media technology, or respond to questions using a social media app on their smartphone teaches them how to respond in a positive manner. Understanding that God has created each person uniquely also allows educators to determine who has natural talents towards technology and who does not. Educators need to keep in mind the truth and justice, and hurting someone via social media causes an injustice. It seems that individuals do not see the injustice of hurting another person by the actions that they perform. Teens seems to think that it is okay to say something negative or mean and that this concept is okay to share in an online format. Here is an example of injustice caused by cyberbullying in a social media setting.

Megan Meier (November 16, 1992 - October 17, 2006) a teenager from Missouri who committed suicide at 14 years old. Her suicide was attributed to cyberbullying through a social media website. Lori Drew, the mother of a former friend, had created a Myspace $^{\circledR}$ account and was using the name of Josh Evans to befriend and eventually destroy Megan. The last message Megan received from Josh included, "The world would be a better place without you." She was found twenty minutes later, hanging by the neck in a closet. Despite attempts to revive her, she was pronounced dead the following day. A federal grand jury indicted Lori Drew on May 15, 2008, on three counts of accessing protected computers without authorization to obtain information to inflict emotional distress. She was convicted in 2009 and faces up to three years in prison and a $\$ 300,000$ fine (Miller \& Hufstedler, 2009).

Instructors need to develop lessons that the administration approve and should consider teaching parents about social media technologies as well as students, so that parents are informed of the process and can communicate as well with their child. Teaching students how to use new 
technology like Twitter $^{\odot}$ could take up more of the limited time that is available for instruction of topics. The ultimate goal of education is having students understand the appropriate actions of being a good digital citizen, how to incorporate this social media concept in a traditional classroom of education, and how to become learners for a lifetime. As Piaget (1983) stated we need to make sure the students understand the process of learning and not just the content that we are teaching. Children are active and motivated learners, and we need to assimilate them to new events or motivate in a way that is consistent with the existing scheme via accommodation in order for them to take what they currently know and transfer the knowledge to form a new concept/scheme.

\section{A Biblical Worldview}

Parents and Teachers must train our students to use time wisely: Psalm 90:12: Teach us to number our days aright, that we may gain a heart of wisdom. Adults must help them learn to avoid activities that can ensnare us: James 1:14: But each one is tempted when, by his own evil desire, he is dragged away and enticed. We must help them to see the value of guarding the purity of our hearts and minds: Proverbs 4:23: Above all else, guard your heart, for it is the wellspring of life. Everyone must encourage them to do all to the glory of God: Ephesians 2:10: For we are God's workmanship, created in Christ Jesus to do good works, which God prepared in advance for us to do (Ryrie, NIV).

A biblical perspective of learning is found in I Corinthians 12 NIV. ${ }^{12}$ The body is a unit, though it is made up of many parts; and though all its parts are many, they form one body. Therefore, it is with Christ. ${ }^{13}$ For we were all baptized by one Spirit into one body--whether Jews or Greeks, slave or free--and we were all given the one Spirit to drink. ${ }^{14}$ Now the body is not made up of one part but of many. ${ }^{18}$ But in fact, God has arranged the parts in the body, every 
one of them, just as he wanted them to be. ${ }^{19}$ If they were all one part, where would the body be? (Ryrie, NIV). Individuals are to use what God has given us for His glory and to help others. Our role as educators is to develop curriculum and instructional methods that let our students use their God-given talents and abilities to serve others. Students can be encouraged to understand their own talents, abilities, and the ability to develop appreciation for all types of academic disciplines in developing their biblical worldview. It is our responsibility as Christian educators to demonstrate the image of God to our students by our actions and choices through social media and instruction of curriculum. Since people are created in the image of God, individuals have free choice to choose how we are going to respond in learning, serving, and educating in topics such as social media technologies. The relationship to God and others is the goal of education and biblically based approach acknowledges that all education is driven by the goal of developing students who would be ambassadors for Christ. Using the technology to enhance the students' knowledge allows them to be used, as God would want them to be used in their future. God has provided individuals with the ability to create social media and has provided the opportunities in educational facilities to teach these concepts to students. If students are unclear on the social media instructions, or are not aware of how to operate in the social media applications, educators need to take the time to address these issues. Educators need to demonstrate what the requirements are and provide many opportunities for learning and activities until all students are comfortable using the social media platforms. All students have the ability to learn and some students may take more tutoring or training than others may. Not everyone has technological tendencies, and teachers have to be patient in establishing this new tool in the classroom.

\section{Personal Application}


In my classroom, I have a curriculum unit on Internet safety (see Appendices E); teaching students about cyberbullying and other social media harms such as sexting, copyright infringement, identity theft, and sexual predators. The students have to learn and complete many different projects using this information concerning Internet Safety. I teach this unit of Internet Safety to all students in a class called Computer Applications. All students have to take Computer Applications as their technology credit in order to graduate. All 117 students completed this course at some time during their high school career or they were currently enrolled in Computer Applications second semester of 2014 at CVCA. I am also on the technology team that gathers the results from all students concerning the cyberbullying questions. We conduct an annual survey concerning cyberbullying to all 850 students who attend CVCA. The class curriculum on the Internet Safety unit has multiple components dealing with cyberbullying such as predator stats, bullying statistics nationally, and how to protect oneself from a cyberbully.

The National Ad Council has launched ads that help educate and communicate to parents, teachers, and students that cyberbullying is a negative for all individuals and must be stopped. The students enjoy visual simulation in learning and this commercial I show to the students who are involved in Computer Applications. The 49-second commercial is a great way to have the students watch, listen, and learn about the hurtful feelings that you can receive when you are a victim of cyberbullying. The message is clear. If it is not something that you would say to a person face-to-face, then you should not write it or post it on-line. To watch the ad, please click on this link - $\underline{\mathrm{https}: / / \mathrm{www} . y o u t u b e . c o m / w a t c h ? v=b d Q B u r X Q O e Q}$

The students are surveyed as part of this unit on their awareness of cyberbullying and if they have been involved in the cyberbullying process as either a victim or a bully. I am also part 
of the technology department and am involved in the actual cyberbullying cases that occur in a private Christian high school. For the past few years, the junior high students have been involved in numerous incidents of cyberbullying. Some research suggests that cyberbullying is more common among middle school students than high school students, (Slonje \& Smith 2008), others point to high school students due to the access that they have to technology (Lenhart, 2009; Lenhart, Madden, \& Hitlin, 2005). Schools report difficulty in preparing policy and discipline that identifies cyberbullying and outlines effective response to cyberbullying (Willard, 2007a, 2007b).

Within the context of Computer Applications class concerning predators showing how social media can cause individuals difficulties if you are not wise in your social media use. Here is an example told by law enforcement to my students.

A student in North Carolina was on-line and she was very careful about what she placed in her online community. She did not have her last name posted anywhere, nor her personal information as she had been taught in her profile. She met a young man online and they began chatting. He was from Colorado and was interested in everything that she was interested in. They liked the same music, the same bands, when he or she had a bad day at school they told each other about their days. They continued to build the relationship for quite a few months and she announced that she had won the softball tournament at her school. The young man did some research and found out which North Carolina school won the softball tournament. One day, the young man wanted to come and meet this young woman in person. He and she made plans secretly to meet. Her parents were not aware of the discussion occurring over the past several months. Their favorite band was coming to a stadium in North Carolina, the young man was coming to North Carolina to vacation, and they thought this was the perfect place to meet. The 
young man told the young woman that he was going to bring an older relative so that this older relative could drive him to the concert. Well the big day arrived, and she received permission to attend the concert and the young man was planning to connect with the young woman in gate $\mathrm{C}$ at the stadium at 5:00 p.m. When the young woman was running a little behind because she had a difficult time trying to decide what to wear to this important meeting. When she arrived to meet the young man, she did not see a teenager but a much older male approximately 40 years old or so. She waited off to the sides to see if a teen would show, after about a half hour, she went up to a security officer because she was feeling a little uneasy and asked if this security officer would go with her to meet the old man to see if he was the uncle of the teen age friend that she was supposed to meet. The old man was the teen in actuality and he was posing as a teen (as an imposter) in the online world. This person was in-charge of a sexual trafficking ring, had already sold the young woman to a person in the Middle East, and had her ticket in his pocket for the flight. By the time that the concert would have been over and her parents realized what occurred, she would have been halfway around the world. The moral of the study is that students are surprised by the ending of this story that it does happen to teens in today's society. This is just one way that social media can cause teenage students distress.

I have also developed administrative policies and procedures for the teachers and school wide on social media safety. The Internet policy document includes what individuals can and

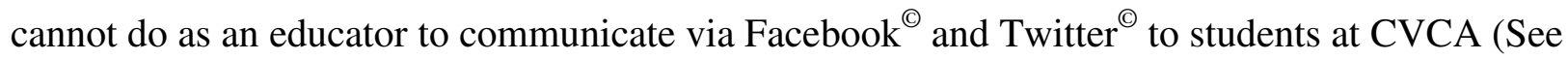
the Appendices D for CVCA's Internet Policy). Since individuals are relationship-oriented and created in the image of God, social media provides us with the opportunity to build relationships with students outside of the classroom. Social media provides an excellent tool to expand classroom activities. Individuals need to be reminded to be careful to provide social media to all 
students and should be aware of how students and parents would accept the activities and assignments using social media tools. Some of the free programs mentioned are excellent to incorporate in classrooms and would not cause an achievement gap to any student that may not be able to afford a smartphone or social media vehicle that has been chosen to be used in an educational setting.

The technology team at CVCA developed a program called Parents on Patrol where the technology team cover a biblical based three hour session for parents to attend to learn about social media safety, technology issues, and protection and plans for how to talk to students about becoming good digital citizenships. Parents are encouraged to attend. In this 3-hour session, topics include computer placement and usage suggestions, social media use, sexting, sexual predators, cyberbullying, pornography addiction using the Internet, texting, texting while driving, what is malware, and mobile devices and protection programs for electronic devices. Parental monitoring on mobile devices and placing their mobile device in a central located place in the home, such as the kitchen, so that the student does not have access to social media during the night is also recommended to the parents. The purpose of this program is to help educate parents on what they should be doing and permitting or allowing for their child in the social media realm. Some of the questions that the team asks and answers in the presentation are "how many people in the world do you think use Facebook?" “On average, how many years of their life does a person spend using media?" "How many cyber predators are likely to be online right now?" "What percentages of teen girls are pressured with sex in a text?" "How many Christians admit that pornography is a problem at home?" "What is the average number of texts a teen sends per month?" "Define Malware". "Can you name three apps for the smart phone?" "When did you last update your anti-virus software?" "Have you used a laptop at a Wi-Fi hot spot?" We 
have done this for the past four years and it is highly attended and very informative and educational. Most parents are not aware of the facts that are presented in the presentation and are appreciative of the opportunity to learn information concerning these topics.

Some verses that I use to talk about social media include Psalm 19:14, Proverbs 3:5-6 and Luke 6:31. All communication should glorify God and serve others. May the words of my mouth and the meditations of my heart be acceptable in Your sight, O Lord, my Rock and my Redeemer (Psalm 19:14). I need to use wisdom to protect others and myself from potential evil. Trust in the Lord with all your heart and do not lean on your own understanding. In all your ways, acknowledge Him, and he will make your paths straight (Proverbs 3:5-6). I need to respect the copyrights of others. Do unto others as you would have them do unto you (Luke 6:31) (Ryrie, NIV p. $737,850,1414)$.

\section{Implications of the Study}

Some examples of the different aspects of the research questions that could be conducted in future studies could include questions such as "What are the effects of social media technology in the public classroom?" "How well can educators communicate with students by using social media technology in a public or private educational classroom?" "Can social networking technology supplement face-to-face educational courses to improve student learning and collaboration?" "Would students who do not have access to social media technology and/or do not participate in social media be at a disadvantage over those who have access and are able to participate in social media technology in a classroom environment?" "Does the implication of Twitter in elective classes such as Marketing or business provide more opportunities than a traditional classroom topic such as English or Math?" "Does engaging in social media technology such as Twitter $^{\odot}$ affect student grades in a classroom?" "Does visual social media 
have more potential than non-visual social media programs such as is YouTube more popular than Facebook?" Future studies will need to confirm the information presented to ensure that social media would be beneficial for high school students in a public or private educational setting.

\section{Conclusion}

This paper has provided a literature review concerning many different articles written on social media technologies and concepts in both a positive and negative connotations. Biblical perspective concerning social media has been revealed. The research study has expressed the procedure, findings, discussion, and further implications in a private Christian high school. Understanding how to incorporate social media technologies as a classroom activity and as a societal tool has been communicated. The interview questions, the questionnaires, the participant's demographics, and the instruments used have been described. Analysis of how this study relates to previous studies has been demonstrated. Drawing from the points discussed above, this paper concludes that as a supplementary learning tool, social media technology holds promise for enhancing student learning at the high school level. However, before the learning effectiveness of social technology is proven by successful implementation strategies, further research will need to be conducted for further consideration. 


\section{References}

Ahn, J. (2011). Digital Divides and Social Network Sites: Which Students Participate in Social Media? Journal of Educational Computing Research, 45(2), 147-163.

Beavers, K. (2014, May 15). Participants Ethnicity Statistics Figure 2. Cuyahoga Falls, OH Beavers, K. (2014, May 15). Social Media Used for in a Week Statistics Figure 3. Cuyahoga Falls, $\mathrm{OH}$

Beavers, K. (2014, May 15). Social Media Personal Profiles Statistics Figure 4. Cuyahoga Falls, $\mathrm{OH}$

Beavers, K. (2014, May 15). Social Media Used for Personal Reasons Statistics Figure 5. Cuyahoga Falls, OH.

Beavers, K. (2014, May 15). Social Media/Internet Applications Used for School Figure 6. Cuyahoga Falls, OH.

Beavers, K. (2014, May 15). Social Media Reasons for Use Figure 7. Cuyahoga Falls, OH. Beavers, K. (2014, May 15). Social Media/Internet Use for a Week Figure 8. Cuyahoga Falls, $\mathrm{OH}$.

Bhat, C., Chang, S., \& Linscott, J. A. (2010). Addressing Cyberbullying as a Media Literacy Issue. New Horizons In Education, 58(3), 34-43.

Bird, S. (2009). Holly Grogan, 15, leapt to her death after abuse from Facebook bullies. The Times. Retrieved from http://www.timesonline.co.uk/tol/news/uk/article6841908.ece

Buus, L. (2012). Scaffolding Teachers Integrate Social Media into a Problem-Based Learning Approach. Electronic Journal of E-Learning, 10(1), 13-22.

Bruning, R., Schraw, G., \& Norby, M. (2011). Cognitive Psychology and Instruction 5th Edition. Boston, MA: Pearson Education, Inc. p. 15, 171, 179 
Burgress, J., \& Green, J. (2009). YouTube. Polity Press: Cambridge

Bynum, S. (2011). Utilizing Social Media to Increase Student Engagement: A Study of Kern County Public Schools. Online Submission

Camacho, M., \& Guilana, S. (2011). From Personal to Social: Learning Environments that Work. Digital Education Review, (20), 24-36.

Cayari, C. (2011). The YouTube Effect: How YouTube Has Provided New Ways to Consume, Create, and Share Music. International Journal Of Education \& The Arts, 12(6),

Cetin, B., Eroglu, Y., Peker, A., Akbaba, S., \& Pepsoy, S. (2012). The Investigation of Relationship among Relational-Interdependent Self-Construal, Cyberbullying, and Psychological Disharmony in Adolescents: An Investigation of Structural Equation Modelling. Educational Sciences: Theory And Practice, 12(2), 646-653.

Collins, A., \& Halverson, R. (2009). Rethinking education in the age of technology. Teacher College Press: New York

CVCA (2014). Cyberbullying statistics from CVCA students in Computer Applications. Cuyahoga Falls, OH: (Kim Beavers, Instructor).

De Abreu, B. (2010). Changing Technology = Empowering Students through Media Literacy Education. New Horizons In Education, 58(3), 26-33.

Dean, A. (2009) What is Facebook. Retrieved February 28, 2014 from http://whatis.techtarget.com/definition/Facebook

Doer, B., Fouz, M., \& Friedrich, T. (2012). Why Rumors Spread So Quickly in Social Networks. Communications of the ACM, 55(6), 70-75.

Fewkes, A. M., \& McCabe, M. (2012). Facebook: Learning Tool or Distraction?. Journal of Digital Learning in Teacher Education, 28(3), 92-98. 
Finkelhor, D. Ormrod, R., Turner, H., \& Hamby, S. (2005). The victimization of children and youth: A comprehensive, national survey. Child Maltreatment. 10, 5-25

Fireollio, P. (2014). Understanding the Basic of STEM Education. Retrieved August 6, 2014 from http://drpfconsults.com/understanding-the-basics-of-stem-education/

Glossary of Education Reform (2014). $21^{\text {st }}$ Century Skills. Retrieved from http://edglossary.org/21st-century-skills/

Gordon, D. (2012). Districts Create Community Connections with Social Media. Education Digest: Essential Readings Condensed For Quick Review, 78(3), 59-62.

Gruber, S. (2013a) Cognitive Development/Vygotsky’s Theory. Cedarville University. Cedarville, Ohio Retrieved November 24, 2013 from http://www.cedarville.edu/moodleclasses/learningtheory.com

Gruber, S. (2013b) Scheme Learning, Meaningful Learning, and Constructivism. Cedarville University. Cedarville, Ohio Retrieved December 2, 2013 from http://ctl2.cedarville.edu/edu6000/2013fa01/week/7

Gruber, S. (2013c) Behaviorist Views of Learning. Learning Theory Professor Notes. Cedarville University. Retrieved October 27, 2013 from http://www.cedarville.edu/learningtheory

Hartley, J. (2009). Uses of YouTube: Digital literacy and the growth of knowledge. In J. Burgess \& J. Green (Eds.). YouTube pp.126-143. Polity Press: Cambridge

Hirschstein, M.K., Edstrom, L. Frey, K., Sell, J. \& MacKenzie, E (2007). Walking the talk in bullying prevention: Teacher implementation variables related to initial impact of the steps to Respect Program. School Psychology Review. 36(1), 3-21.

Hung, H., \& Yuen, S. (2010). Educational Use of Social Networking Technology in Higher Education. Teaching In Higher Education, 15(6), 703-714. 
I-Safe.org. (2014). The Leader in E-Safety Education Solutions. Retrieved August 5, 2014, from http://www.i-safe.org/wp/

Jones, V. R. (2014). Teaching STEM: 21st century skills. Children's Technology \& Engineering, 18(4), 11-13.

Junco, R. R., Heiberger, G. G., \& Loken, E. E. (2011). The effect of Twitter@ on college student engagement and grades. Journal of Computer Assisted Learning, 27(2), 119-132. doi:10.1111/j.1365-2729.2010.00387.x

Kessler (S). (2010). The Case for Social Media in Schools, MASHABLE Retrieved from http://mashable.com/2010/09/29/social-media-in-school/

Kolus, K. (2010). Let's talk about social media: What's your message? Long-Term Living: For the Continuing Care Professional, 59(10), 24-30.

Kowalski, R., \& Limber, S. (2007). Electronic bullying among middle school students. Journal of Adolescent Health. 41, 22-30

Kowalski, R. \& Limber S. \& Agatston, P. (2008). Cyberbullying: Bullying in the digital age. Malden, MA: Blackwell Publishing.

Latta, M., Thompson, C., Ruthmann, A., \& Thibeault, M. (2012). Bringing in the Change. The Education Digest. Retrieved from www.eddigest.com

Lange, P. (2008). (Mis)conceptions about YouTube. In G. Lovink \& S. Niederer (Eds.), Video vortex reader: Responses to YouTube pp.87-100. Institute of Network Cultures: Amsterdam.

Lenhart, A. (2009). Teens and mobile phones over the past five years: PEW Internet looks back. Retrieved August 19, 2011 from http://www.pewinternet.org/Reports/2009/14-Teensand-Mobile-Phones Data-Memo.aspz 
Lenhart A., Madden, M., \& Hitlin, P. (2005). Teens and technology. Retrieved August 19, 2011, from http://www.pweinternet.org/Reports/2005/Teens-and-Technology.aspx

Levy, P. (2011) Confronting Cyberbullying. The Journal, Volume 38, (5), 25-27.

Lin, M., Hoffman, E., \& Borengasser, C. (2013). Is Social Media Too Social for Class? A Case Study of Twitter Use. Techtrends: Linking Research \& Practice To Improve Learning, 57(2), 39-45. doi:10.1007/s11528-013-0644-2

Madhava, R. (2011). 10 Things to Know About Preserving Social Media. Information Management Journal, 45(5), 33-37.

Merriam-Webster, Incorporated. (2014). Technology. Retrieved from Merriam-Webster: http://www.merriam-webster.com/dictionary/technology

Miller, J. D., \& Hufstedler, S. M., (2009). Cyberbullying Knows No Borders. Refereed paper presented at 'Teacher education crossing borders: Cultures, contexts, communities and curriculum' the annual conference of the Australian Teacher Education Association, (ATEA), Albury, 28 June - 1 July.

Moran, M., Seaman, J., Tinti-Kane, H., \& Babson Survey Research, G. (2011). Teaching, Learning, and Sharing: How Today's Higher Education Faculty Use Social Media. Babson Survey Research Group

National Crime Prevention Council (2009). Cyberbullying. Accessed February 2009.Retrieved from http://www.ncpc.org/topics/by-audience/parents/bullying/cyberbullying

Nickel, R. (2006). Staying Safe In a Wired World: A parent's guide to the Internet. Nickel Publishing: Toronto Canada

Palfrey, J., \& Gasser, U. (2008). Born Digital: Understanding the First Generation of Digital Natives. Basic Books: New York 
Papandrea, M. R. (2012). "Social Media, Public School Teachers, and the First Amendment." North Carolina Law Review 90, 1597-1642.

Partnership for 21st Century Skills (2014). Washington, DC 20001 Retrieved August 6, 2014, from http://www.p21.org

Patchin, J. W., \& Hinduja, S. (2006). Bullies move beyond the schoolyard. Youth Violence and Juvenile Justice. 4, 148-169

Patchin, J. W., \& Hinduja, S. (2010). Bullying, cyberbullying, and suicide. Archieves of Suicide Research. 14, 206-221.

Payne, A., Gottfredson, D., \& Gottfredson, G. (2006). School predictors of the intensity of implementation of school based prevention programs: Results from a national study. Prevention Science. 7, 225-237

Peters, J. \& Ling, E. (2014). Teaching Social Media from an Educator's Perspective Interview. Cuyahoga Valley Christian Academy. Cuyahoga Falls, OH (K. Beavers, Interviewer).

Piaget, J. (1983). Piaget's Theory. In P. Mussen (ed). Handbook of Child Psychology. 4(1)

Pikalek, A. J. (2010). Navigating the Social Media Learning Curve. Continuing Higher Education Review, 74150-160.

Poellhuber, B., \& Anderson, T. (2011). Distance Students' Readiness for Social Media and Collaboration. International Review of Research in Open and Distance Learning, 12(6), 102-125.

Redman, C., Trapani, F., \& Australian Association for Research in Education, (. (2012). Experiencing New Technology: Exploring Pre-Service Teachers' Perceptions and Reflections upon the Affordances of Social Media. Australian Association for Research in Education 
Rivero, V. (2011). We're Talking Social Media in Education. Internet@ Schools, 18(3), 12-15.

Robinson, K. (2009). The Element. Penguin, London, UK

Rouse, M. (2014). Instagram. TechTarget. Retrieved July 29, 2014 from http://searchcio.techtarget.com/definition/Instagram

Ryrie, C. C. (1986). Psalm 139:14, The Holy Bible, New Intervational Version. Chicago IL: Moody Press. p.837

Shim, J. (2011). Twitter@, Google, iPhone/iPad, and Facebook (TGIF) and Smart TechnologyEnvironments: How Well Do Educators Communicate with Students via TGIF? Communications of AIS, 2011(29), 657-672.

Shaukat, O. (2011). Kowalski v. Berkeley County Schools. Retrieved from http://www. http://www.mddefensecounsel.org/cases/kowalski.html Retrieved actual case from U.S. www.ca4.uscourts.gov. Case Number is 101098.P

Slonje, R. \& Smith, P. (2008). Cyberbullying: Another main type of bullying? Scandinavian Journal of Psychology 49. 147-154

Stauffer, S., Heath, M., Coyne, S., \& Ferrin, S. (2012). High School Teachers' Perceptions of Cyberbullying Prevention and Intervention Strategies. Psychology In The Schools, 49(4), $352-367$.

Tech Factor (2009, March) Twitter@ Retrieved February 28, 2014 from http://www.techterms.com/definition/Twitter@)

Turvey, K. (2012). Questioning the Character and Significance of Convergence between Social Network and Professional Practices in Teacher Education. British Journal of Educational Technology, 43(5), 739-753. 
Vandebosch, H. \& Van Cleemput, K. (2007). Cyberbullying among youngesters. Conference Papers - International Communication Association. Retrieved August 19, 2011 from Communication \& Mass Media Complete database.

VanDoorn, G., \& Eklund, A. A. (2013). Face to Facebook: Social Media and the Learning and Teaching Potential of Symmetrical, Synchronous Communication. Journal of University Teaching and Learning Practice, 10(1),

Wagner, T. (2008) High School Teaching $21^{\text {st }}$ Century: Preparing Students for College Alliance for Excellent Education Brief 2007. Cambridge, MA.

Whitehouse, G. (2010). Newsgathering and Privacy: Expanding Ethics Codes to Reflect Change In the Digital Media Age. Journal of Mass Media Ethics, 25(4), 310-327. doi:10.1080/08900523.2010.512827

Willard, N. (2007a). The authority and responsibility of school officials in responding to cyberbullying. Journal of Adolescent Health. 41. 64-65

Willard, N. (2007b). Educator's guide to cyberbullying: Addressing the harm caused by online social cruelty. Retrieved August 19, 2011, from http://www.asdk12.org/MiddleLink/AVB/bully topics/EducatorsGuide Cyberbullying.p $\underline{\text { df }}$

Ybarra, M. \& Mitchell, K. (2004a). Youth engaging in online harrassment: Associations with caregiver-child relationships, Internet use, and personal characteristics. Journal of Adolescence. 27. 319-336 
Appendix A

\section{Social Media Survey Questionnaire}

Name of the individual:

Type of internet connection:

(DSL, Cable, Dial Up)

1. How many hours do you spend over the Internet every day?

○ $0-5$ hours

- 6-10 hours

- 11-15 hours

○ $16-20$ hours

○ 21-24 hours

2. Which is your primary Internet search engine?

○ Google.com

- Yahoo.com

○ Bing

3. In which of the following social media networks do you have a personal profile?

○ Facebook

○ Google +

○ LinkedIn

○ MySpace

○ Flickr

○ Twitter@

○ StumbleUpon

- Snapfish

○ Instagram

4. How many friends do you have on your primary social network site?

○ 1-25

○ 26-50

○ 51-75

- 76-100

- More than 100 
5. What is the primary reason for using a social media network?

- Keep in touch with family and friends

- Share pictures, videos, and games

- Meet new people

- Find old friends

- Make new business contacts

- Keep in touch with current business contacts

- Promote business

- Promote ideas

6. Have you ever purchased a product or service from a social network? If yes, then specify

○ Yes

○ No

If yes, what Product / Service:

7. How frequently do you use each of the social media applications listed below for work/professional reasons?

Facebook

Google+

LinkedIn

Twitter@

YouTube

○ Daily

- A few times a week

Name:

- Once a week

- A few times a month

Name:

Once a month

Name:

Name:

Name:

- Less frequently than once a month

Name:

o Never

Name:

8. How frequently do you use each of the social media applications listed below for personal reasons?

Facebook

Google+

LinkedIn

Twitter@

YouTube

○ Daily

- A few times a week

Name:

- Once a week

- A few times a month

Name:

Name:

Name: 
○ Once a month

- Less frequently than once a month

- Never
Name:

Name:

Name:

9. Why do you use social media for personal reasons? (Select all that apply)

- Communication

- Conduct Research

- Customer Service

o Job Search

- Marketing

○ Networking

- News

- Recruiting

O Other (specify):

10. How important is social media to your personal life?

- Very important

- Somewhat important

- Neither important nor unimportant

- Somewhat unimportant

○ Very unimportant

11. In general, how satisfied are you with the outcome of your personal social media activities?

○ Very satisfied

- Somewhat satisfied

- Neither satisfied nor unsatisfied

- Somewhat unsatisfied

○ Very unsatisfied

12. Do you use any social media monitoring or measurement tools?

○ Yes

○ No

13. Which do you value more about social media, the sending/sharing of information or receiving/viewing of information?

- Sending/Sharing

- Receiving/Viewing

- Value both equally 
14. How many hours do you spend on the Internet every week?
○ 0 -5 hours
○ 6-10 hours
- 10-20 hours
○ 21-30 hours
- 31- 40 hours
- 41-50 hours
○ 51-60 hours
- 61-70 hours
○ 71-80 hours
○ Over 80 hours

15. Do you use social media in any of your current classes?

$$
\begin{array}{ll}
\circ & \text { Yes } \\
\circ & \text { No }
\end{array}
$$

If yes, which class(es)?

16. What is your age?

○ $12-16$

○ $17-18$

○ $19-24$

○ $25-30$

○ 31-- 40

○ $41-50$

○ $51-60$

○ $61-70$

- 71 - older

17. What is your gender?

○ Male

○ Female

18. What is your race/ethnicity?

$\square$ American Indian or Native Alaskan

$\ulcorner$ Asian

$\square$ African American

$\ulcorner$ Caucasian

$\square$ Hispanic or Latino

$\square$ Native Hawaiian or Other Pacific Islander 


\section{Appendix B}

\section{Interview Questions}

\section{Questions}

1. Do you know how to use computers?

2. Do you know how to use Social Media technologies?

3. Whom do you follow on Twitter $^{\oplus}$ ?

4. Please tell me some of your favorite tweets?

5. What social media applications do you use on a regular basis?

6. How often do you use social media on a daily basis - a few minutes, about an hour, less than four hours total, or between four and eight hours total?

7. Why do you feel that social media is a good method to stay connected to family and friends?

8. Do you feel if educators incorporated social media in their classes you would learn more and be more engaged and why? 
Appendix C

\section{CONSENT FOR PARTICIPATION in SOCIAL MEDIA IN THE CLASSROOM RESEARCH PROJECT}

TITLE: Social Media in the Classroom

I agree to allow my child to take part in a research study titled "Social Media in the Classroom", which is being conducted by Mrs. Kimberly K. Beavers, attending Cedarville University, and is a Faculty Member at CVCA, 330 ext. $\square$ under the direction of Dr. Stephen Gruber, @ @ cedarville.edu, 937 participation is voluntary; I and my child can refuse to participate or stop taking part at any time without giving any reason, and without penalty. I can ask to have information related to me or to my child returned to me, removed from the research records, or destroyed.

\section{REASON/PURPOSE:}

The purpose of the study is determine if a student's learning and engagement would increase with the use of social media technology such as Twitter@ /Facebook in an educational classroom.

Since I teach technology courses at CVCA, I am curious to see if educational instruction is improved by educators who use social media in their traditional classrooms as compared to instructors/students who do not use social media in the traditional education instruction. The questionnaire and interview will be conducted to determine if there are benefits for incorporating social media in traditional classrooms or not.

\section{BENEFITS:}

Students will not benefit directly from this research. There are no benefits given for participating in the study:

\section{COMPENSATION/COSTS/REIMBURSEMENT:}

There are not any compensation/costs/or reimbursements for participating in the study. The only cost involved would be 15 minutes to an hour of your time.

\section{PROCEDURES:}

If students volunteer to take part in this study, students will be asked to do the following things: Complete a questionnaire during class.

If chosen to complete a personal interview, a half hour of your time will be requested during your study hall, lunch period, before or after school depending on your schedule.

Each interview will last approximately thirty minutes. The questionnaire will be conducted during class time. All students will have a homework assignment to complete, if you have choose not to participate, you may begin working on the homework assignment in class, so no student will be singled out during the questionnaire completion time.

Instructions will be given to the students concerning the questionnaire and the homework assignment. 
Students will complete the questionnaire on their own.

They will turn in the questionnaire to the homework bin.

The questionnaires will have their names on them and what grade they are currently in. (The purpose for their name and grade is to determine the demographics for the 30 individuals to be interviewed.)

Once completed with the questionnaire the students are finished with the research project component unless selected for the interview process.

If selected for the interview process, then a request for their time during study hall, lunch, before or after school would be made through the student's email.

The interview would be set up at their convenience.

The interview will last up to 30 minutes.

Once the interview is completed, then their participation will be completed.

The interview will be recorded for recall purposes.

\section{DISCOMFORTS OR STRESSES:}

No discomforts or stresses are expected.

The discomforts or stresses that may be faced during this research are minimal.

The discomfort or stresses related may be the questionnaire questions; or the time involved for the interview process. It would be a relaxed atmosphere and very little nervous energy

expended.

\section{RISKS:}

No risks are expected.

\section{DECEPTION:}

In order to make this study a valid one, some information about my child's participation will be withheld until after the study.

\section{CONFIDENTIAL, ANONYMOUS, OR PUBLIC:}

The records will be confidential. The records will be deleted once the data has been compiled to complete and finalize the research project.

Information will not be released to any other party for any reason.

The interview will be audio recorded for recall purposes. No one will have access to the recordings except for Mrs. Beavers and the information provided will be used for educational purposes, and the files will be deleted when the research project will be finalized.

Describe the standard procedures.

A. Any information obtained in connection with this study that can be identified with me will remain confidential unless required by law.

B. Any individually-identifiable information about me will be kept confidential. An exception to confidentiality involves information revealed concerning suicide, homicide, or child abuse which must be reported as required by law, or if the researchers are required to provide information by a judge. 


\section{FURTHER QUESTIONS:}

Mrs. Beavers will answer any further questions about the research now or during the course of the project, and can be reached by telephone at: $330-$

\section{FINAL AGREEMENT \& CONSENT FORM COPY:}

I understand the procedures described above. My questions have been answered to my satisfaction, and I agree to participate in this study. I have been given a copy of this form.

\section{CONSENT FORM SIGNATURE LINES FORMAT:}

Please sign both copies, keep one and return one to the researcher.

Name of Researcher: __ Kimberly K. Beavers Date: $\underline{\text { May 1, } 2014}$

Signature:

Telephone:_330-

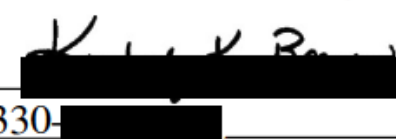

Email:

@ cedarville.edu

Name of Participant: Date:

Signature:

\section{PARENTAL PERMISSION FORM SIGNATURE LINES FORMAT:}

Please sign both copies, keep one and return one to the researcher.

Name of Researcher: __ Kimberly K. Beavers Date: May 10, 2014

Signature:

Telephone:_330-

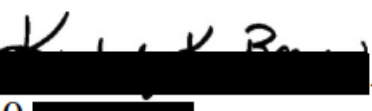

Name of Parent/Guardian: Date:

Signature:

Additional questions or problems regarding your child's rights as a research participant should be addressed to Dr. Dennis Sullivan, Chair, Institutional Review Board, Cedarville University, Cedarville, OH 45314; Telephone (937)766- 
Appendix D

\section{Cuyahoga Valley Christian Academy Internet Acceptable Use Policy}

Effective August 2010

Preamble

Respect for school authority is a fundamental principle at CVCA. Students are expected to demonstrate a positive and respectful attitude toward all members of the administration, faculty, and staff. Particular care should be taken to honor those involved in sacred trust of teaching. The Academy and its property have been dedicated to the Lord and to His service. We are striving to be faithful stewards of this responsibility. Since students become stewards with us when they join Cuyahoga Valley Christian Academy, they are expected to accept that responsibility; therefore, any action that damages or defaces the property will lead to disciplinary action.

\section{Rationale}

Cuyahoga Valley Christian Academy believes that the Internet has much to offer students with its variety and accessibility of resources. It is the school's goal to educate students about efficient, ethical, and appropriate use of those resources. Within the context of CVCA's mission statement as a school, the Internet connection will be used to meet the goals within the school's curriculum. Specifically, students will have the opportunity to enhance their learning through the following:

1. A wealth of additional resources for reference and research

2. Consulting with experts in a variety of fields

3. Communicating with other students and individuals in areas or situations under study

4. Learning to conduct searches, evaluate resources, and locate relevant material

5. Interacting with up-to-date primary source

\section{$\underline{\text { Provisions }}$}

In order to assist students in learning to use the Internet correctly, the Academy will do everything it can to ensure students appropriate access to the available resources. This includes providing the following:

1. A reliable connection 
2. Training for students and parents that clearly spells out appropriate and inappropriate materials. Students will also be given general instruction about what is available on the Internet and how to conduct efficient and successful searches and finally, how to acquire hard copies of materials for their research needs. They will also receive instruction in etiquette as well as proper evaluation and citation of reference materials.

It is to be understood that Internet access for students is a privilege, not a right. All users of the Internet will agree to the following Code of Ethics:

I will strive to act in all situations with honesty, integrity, and respect for the rights of others and to help others to behave in a similar fashion. I will make a conscious effort to be a good testimony to my fellow students, faculty members, and others I communicate with on the Internet. I agree to follow Cuyahoga Valley Christian Academy's basic rules. I will strive to apply Philippians 4:8 to my electronic communication, "Finally brothers, whatever is true, whatever is noble, whatever is right, whatever is pure, whatever is lovely, whatever is admirable-if anything is excellent or praiseworthy_think about such things."

\section{Unacceptable Practices}

The Internet user is held responsible for his/her actions whenever using the Internet. Unacceptable uses of the network will result in the suspension or loss of these privileges. Some examples of unacceptable use include (but are not limited to):

1. Using the network for any illegal activity.

2. Defacing or disrupting the equipment or system performance. Any security problems must be reported to the technology coordinator and not shared with other users.

3. Vandalizing the data of another user.

4. Wastefully using finite resources after being warned and instructed as to proper use.

5. Gaining unauthorized access to resources, including attempting to get around any censor software installed on a computer with internet access.

6. Invading the privacy of individuals including reading mail that belongs to others without their permission.

7. Using an account owned by another user-with or without that user's permission.

8. Posting personal communications without the author's consent or posting material containing information not meant for public view.

9. Posting rude or inappropriate messages. 
10. Downloading viruses or attempting to circumvent virus protection programs.

11. Violating the spirit of Cuyahoga Valley Christian Academy's Mission Statement. "Educating and Cultivating Servants for Christ"

12. Not asking permission before using any color printers (this has a daily limit, and individuals will be charged with a fee for personal use).

13. Pornography.

14. Slanderous or derogatory information about any person, race, or gender.

15. Uploading images of any CVCA community member to off-campus websites or blogs.

16. Using the Internet to intentionally harm the reputation of any CVCA community member or family.

17. Downloading or duplicating copyrighted material in any form without expressed permission.

\section{Disclaimers}

The Internet user and his/her parents must understand that he/she uses the Internet at his/her own risk. Considering the provisions mentioned above, CVCA cannot assume responsibility for any of the following:

1. The reliability of the content of a source received by a user. Students must evaluate and cite sources appropriately.

2. Costs that the student incurs if he/she requests a product or service for a fee.

3. Any consequences of disruption in service that may result in lack of resources. Though every effort will be made to ensure a reliable connection, there may be times when the Internet service is down or scheduled for use by teachers, classes, or students.

4. Guaranteeing privacy of mail. Though we do support privacy of email, users must not assume that this is guaranteed. The technology staff and the headmaster reserve the right to investigate possible misuses or to monitor any email that comes through CVCA computers.

5. While CVCA employs an internet filtering service, no filter is $100 \%$ effective. CVCA cannot guarantee that all inappropriate material will always be blocked. 
In exchange for the use of Cuyahoga Valley Christian Academy's computer system, students understand and agree to the following:

1. Use of network is a privilege, which may be revoked at any time for any conduct deemed inappropriate.

2. Users need to be aware that Internet sites reflect only the opinions of their designers/producers and not that of Cuyahoga Valley Christian Academy. Sites should be evaluated for source reliability and validity before being considered for inclusion into academic research.

3. System administrators reserve the right to review any material stored in files, which are generally accessible to others and will edit or remove any material, which the staff, in its sole discretion, believes, may violate the above standards. It is expressly forbidden for users to use any CVCA resource to obtain, view, download, store, forward, or otherwise access illicit materials. Exceptions to this policy may be innocent files or Facebook, in which students are allowed a quota time of thirty minutes a day.

4. CVCA user who violates the above standards or attempts to log in as another user will have his/her account disabled.

5. Electronic mail is not guaranteed to be private. System administrators can access mail, and needs to approve all standard distribution list emails. Programming errors may cause servers to misdirect messages. These considerations should be kept in mind when corresponding with others.

6. The user should not reveal any password to anyone in order to preserve the privacy of the account.

7. The network is a shared resource with finite capacities that users should be considerate when transferring or storing large files on the CVCA resources and that any use of the network, which disrupts other users or seriously degrades performance may be determined to be improper by the system administrator and appropriate action will be taken.

8. All information services and features contained on the CVCA network are intended for the private use of its users and any commercial or other unauthorized use of those materials, in any form, is expressly forbidden.

9. All information contained on the CVCA network is placed there for educational and general information purposes.

10. CVCA does not warrant that the functions of the system will meet any specific requirements a user may have, or that it will be error free or uninterrupted; nor shall it be liable for any direct or indirect, incidental, or consequential damages (including lost data, information, or profits) sustained or incurred in connection with the use, operation, or inability to use the system. CVCA shall not be liable for any damage incurred due to harmful programs (including computer 
viruses), which on rare occasions may propagate through networks such as CVCA network and the internet.

11. The CVCA network is intended for the exclusive use of its registered users, who are responsible for the use of their password and account. Any problems, which arise from the use of a particular account, are the responsibility of the account holder. Any misuse will result in suspension of the account privileges. Use of an account by someone other than the registered account holder may also be grounds for loss of privileges.

12. Students will abide by such rules or regulations of system usage as may be decreed from time to time by the administrators of the CVCA network.

13. Excessive use of websites that are deemed by the administration to be unacceptable/non-academic may be blocked or permitted on a limited basis.

14. In consideration of the privilege of using the CVCA network and in consideration of having access to information contained therein, I release CVCA, its operators, and any institutions with which CVCA may be affiliated, will not be held responsible for any and all claims of any nature arising from the use, or inability to use, the CVCA network and the Internet 


\title{
Appendices E
}

\author{
Internet Safety Unit
}

\section{Create a MLA Paper}

Idea: All communication should glorify God and serve others.

Verse: May the words of my mouth and the meditations of my heart be acceptable in your sight, $O$ Lord, my Rock and my Redeemer (Psalm 19:14).

- Topic: Dangers of Sexting and Texting (addiction and texting while driving)

- Source of information: Use these sites or others that you find on the subjects.

- Sexting:

- http://familyinternet.about.com/od/computingsafetyprivacy/a/sexting what.htm

- http://www.merriam-webster.com/dictionary/sexting

- http://ktla.com/2013/05/09/teens-could-face-charges-in-sexting-scandal/\#axzz2SopwxMIG

- Texting while driving:

- $\quad$ http://www.caranddriver.com/features/texting-while-driving-how-dangerous-is-it

- http://www.fcc.gov/guides/texting-while-driving

- http://www.att.com/gen/press-room?pid=23181 Texting Addiction:

- $\quad$ http://www.blacklistednews.com/?news id=10300

- $\quad$ http://newcanaan.patch.com/groups/opinion/p/texting-a-dangerous-addiction

- http://www.promises.com/articles/teens/teens-texting-addiction/

- Source of information for verses: www.Biblegateway.com. Find Bible verses on helpful and hurtful speech.

- Save Paper as: Mobile Phone Use.

- Write an MLA two page paper that presents what you learned about the dangers of misusing cell phones. You need three Works Cited entries and in-text citations for each reference and after each verse. You may not copy and paste anything from the internet. You will use websites listed or other sites that you found in researching the topics, and Biblegateway.com. Wikipedia is not acceptable. Be sure to include all elements in the MLA paper and in the work cited paper.

2. Access

\section{Idea: I need to respect the copyrights of artists.}

Verse: Do unto others as you would have them do unto you (Luke 6:31).

Topic: Duplication of CDs and DVDs

Source of Information: Internet. You need to find five websites that give information on music and video copyrights.

Graded item: Access Database Report entitled Copyright Information Websites that displays five helpful websites in regards to copyright. Include the following three fields:

Website Name (text field), URL (hyperlink field), Use This Site to Learn: (notes field) Create a table. Create a report, and save it as copyright information websites, and print it. You will need to find five websites at least. Remember the note about Primary Key. 
3. Create a Poster or Brochure in one of these programs - Publisher, Photoshop, Illustrator, In-Design that contains basic Internet Safety information and graphics. Save as posters, and print it.

Idea: I need to use wisdom to protect others and myself from potential evil.

Verse: Trust in the Lord with all your heart and do not lean on your own understanding. In all your ways, acknowledge Him, and he will make your paths straight (Proverbs 3:5-6).

Topic: Sexual predators and Cyber bullies

Source of Information: wiredsafety.com and SafeTeens.com

Graded item: Save As Cyber Predators. Using a Graphic Design software program, make a onepage poster $\left(8 \frac{1}{2} \times 11\right)$ or one three panel brochure that would be suitable to hang in a GRADE

SCHOOL. Combine text and graphics in an attractive way to accomplish the following:

- Define cyber bully and sexual predator

- Provide some statistics

- List some rules to guide grade-school children to steer clear of sexual predators and cyber bullies

- Warn children never to engage in predator behavior, and to report it to an adult when they are aware of it.

4. Create an Excel spreadsheet that reflects stats of Internet Safety Issues. Create a chart of your choice to go along with your spreadsheet. Be sure to have three Excel pages when finished. You need the key on your excel chart. Here are some sites for you to use.

\begin{tabular}{|l|l|l|}
\hline \multicolumn{1}{|c|}{$\begin{array}{c}\text { Website } \\
\text { Name }\end{array}$} & \multicolumn{1}{c|}{ Description } & URL \\
\hline SafeWave & General Stats & $\underline{\text { http://www.safewave.org/index.php?option=com content\&task=view\&id= }}$ \\
\hline $\begin{array}{l}\text { Enough is } \\
\text { Enough }\end{array}$ & $\begin{array}{l}\text { Predator } \\
\text { Stats }\end{array}$ & $\underline{\text { http://www.internetsafety101.org/Predatorstatistics.htm }}$ \\
\hline $\begin{array}{l}\text { Enough is } \\
\text { Enough }\end{array}$ & $\begin{array}{l}\text { Full Library } \\
\text { of Stats }\end{array}$ & $\underline{\text { http://www.enough.org/inside.php?id=3K03RC4LOO }}$ \\
\hline $\begin{array}{l}\text { Bullying } \\
\text { Statistics }\end{array}$ & $\begin{array}{l}\text { Cyber } \\
\text { Bullying }\end{array}$ & $\underline{\text { http://www.bullyingstatistics.org/ }}$ \\
\hline iSafe & $\begin{array}{l}\text { Cyber } \\
\text { Bullying }\end{array}$ & $\underline{\text { http://www.isafe.org/outreach/media/media cyber bullying }}$ \\
\hline
\end{tabular}

The Hamilton Hill High School Administration took a survey of students across a threeyear period to examine cyber-bullying trends among the student body. Below you can see their findings. Please use the data below to compile a spreadsheet. Then use that spreadsheet to complete the rest of the questions listed.

- In the 2012-2013 school year, 250 students claimed to be victims of cyberbullying, 57 said they witnessed cyberbullying, and 92 students said they cyberbullied another student.

- In the 2011-12 school year, 247 students claimed to be victims of cyberbullying, 89 said they witnessed cyberbullying, and 87 students said they cyberbullied another student. 
- In the 2010-11 school year, 268 students claimed to be victims of cyberbullying, 62 said they witnessed cyberbullying, and 102 said they cyberbullied another student.

The total number of students in the school was 1100 each year and every student completed a survey each year.

With this information, please compile a spreadsheet that calculates the total number of students involved in each of the three categories of cyberbullying. You also need to calculate the total number of students involved each school year, the percentage of the student body that was involved in cyberbullying each year, and the most common and least common areas of involvement (max and min).

Once you complete your spreadsheet, please create a chart that displays this information as well.

5. Create a two page webpage announcing your project in Dreamweaver. Save as Internet Safety website, open in the browser, and print both pages. Be sure to link the two pages together. A suggestion would be to have one page for victims, and one page on stats or information. Save your website in a folder on the AA color Printing folder with your name.

6. PowerPoint Presentation

Idea: I need to use wisdom to protect others and myself from potential evil.

Verse: Trust in the Lord with all your heart and do not lean on your own understanding. In all your ways, acknowledge Him, and he will make your paths straight (Proverbs 3:5-6).

- Topic: Identity Theft

- Source of information: internet. Look anywhere you need to today about identity theft in order to create your PowerPoint.

- Save As: Identity Protection. Create a PowerPoint presentation that addresses these questions:

1. What is identity theft?

2. What is phishing?

3. What can someone do with my identity?

4. What can I do if my identity is stolen?

5. What places can help me if my identity is stolen?

6. What rules should I follow to avoid identity theft?

- Create 10+ slides: the first is the title slide; the last gives any websites you consulted

- Use one design theme

- Use animation and transitions that enhance understanding and do not distract from your message

- Use the six by six rule for text

- Find graphics that enhance the presentation: give the URL on the last page for each image that was not from MS clipart.

- Extra Credit - Hyperlink your Table of Content

- Save your presentation to the AA Color Printing folder with your name 
7. Create a cover for your entire packet. Use Publisher and have a graphic, your name, period, class, and date on the cover.

8. Create a letter address to your instructor. The address is Teacher's Name, CVCA, 4687 Wyoga Lake Road, Cuyahoga Falls, $\mathrm{OH} 44224$. The topic of your letter is what you have learned from the different areas you have researched. It needs to be on your Master Letterhead. You need to be sure to include all components of a letter. The following information needs to be attached: Exam Cover, Research Paper, Report, Poster, Excel information and chart, PowerPoint, and websites.

9. Create a memo to Mrs. Beavers. Please state what she should tell parents in regards to Internet Safety for their child. Be sure to provide examples in the three paragraphs of what to look for and how to stay safe on line. Be sure to sign the document before including it in your final exam packet. 